\title{
Early-Middle Pleistocene environmental and biotic transition in north-western Armenia, southern Caucasus
}

\author{
Alexey S. Tesakov, Alexandra N. Simakova, Pavel D. Frolov, \\ Eugenia K. Sytchevskaya, Elena V. Syromyatnikova, \\ Irina V. Foronova, Eugenia A. Shalaeva, and Vladimir G. Trifonov
}

\begin{abstract}
Quaternary biota of north-western Armenia is studied from several localities in the Ani and Arapi fluvial formations of the Shirak and Upper Akhuryan sedimentary basins. Palynology of lacustrine deposits of the Ani Formation indicates cyclic alternation of forest-steppe and steppe coenoses in the Shirak Depression. The patchy pollen record from the sections of the Arapi Formation indicates forest-steppe coenoses. Aquatic molluscs from the Ani Formation are dominated by gastropods and dreissenid bivalves. Molluscs of the Arapi Formation are characterised by limnophilic freshwater species with mostly extant forms. The Arapi deposits yielded remains of fishes, amphibians, and small mammals. The freshwater fish assemblage comprises cyprinid species that derived from the earlier Plio-Pleistocene fish communities of Armenia. The assemblage indicates lacustrine and river habitats with rocky bottoms and the presence of water plants overgrowth. The herpetofauna from the Arapi Formation includes remains of anuran amphibians that indicate aquatic habitats. Small mammals include Sorex cf. runtonensis, Neomys cf. hintoni, Ochotona sp., Mimomys intermedius, Terricola sp., Microtus gr. nutiensis, Prolagurus pannonicus transylvanicus, and Ellobius pomeli. This fauna characterises the Leninakan (Gyumri) faunal assemblage correlated to the late Biharian of the European land mammal biochronology, Tiraspol faunal complex of Eastern Europe, and the Cromerian of NW Europe. The studied record has an important biogeographic significance for the southern rim of the Ponto-Caspian region. It shows the complex history of the biotic exchanges and polygenous origin of the terrestrial communities in the southern Caucasus. Radiometric, paleomagnetic, and biotic control make it possible to date the Ani deposits to late Early and earliest Middle Pleistocene. The age of the Arapi formation is early Middle Pleistocene older than 0.6 Ma. The main trend of landscape evolution in the region between ca. 1.5-0.7 $\mathrm{Ma}$ is a transition from forest-steppe to steppe conditions.
\end{abstract}

Tesakov, Alexey S., Simakova, Alexandra N., Frolov, Pavel D., Sytchevskaya, Eugenia K., Syromyatnikova, Elena V., Foronova, Irina V., Shalaeva, Eugenia A., and Trifonov, Vladimir G. 2019. Early-Middle Pleistocene environmental and biotic transition in northwestern Armenia, southern Caucasus. Palaeontologia Electronica 22.2.25A 1-39. https://doi.org/10.26879/916 palaeo-electronica.org/content/2019/2518-pleistocene-biota-from-armenia 
Alexey S. Tesakov. Geological Institute of the Russian Academy of Sciences, Pyzhevsky per., 7, Moscow, 119017 Russia; tesak@ginras.ru; tesak-ov@yandex.ru

Alexandra N. Simakova. Russian Academy of Sciences, Pyzhevsky lane 7, Moscow, 119017 Russia; simak2001@mail.ru

Pavel D. Frolov. Geological Institute, Russian Academy of Sciences, Pyzhevsky per., 7, Moscow 119017 Russia and Laboratory of Macroecology and Biogeography of Invertebrates, Saint-Petersburg State University, Universitetskaya Emb. 7-9, Saint-Petersburg, 199034 Russia; Pavlentiy987@mail.ru Eugenia K. Sytchevskaya. A.A. Borissiak Paleontological Institute, Russian Academy of Sciences, Profsoyuznaya ul., 123, Moscow, 117997 Russia; sch-oks@mail.ru

Elena V. Syromyatnikova. A.A. Borissiak Paleontological Institute, Russian Academy of Sciences, Profsoyuznaya ul., 123, Moscow, 117997 Russia; esyromyatnikova@gmail.com; sev@paleo.ru and Zoological Institute, Russian Academy of Sciences, Universitetskaya nab., 1, St. Petersburg, 199034 Russia.

Irina V. Foronova. V.S. Sobolev Institute of Geology and Mineralogy, Siberian Branch of the Russian Academy of Sciences, Koptyuga pr., 3, Novosibirsk, 630090 Russia; foronova@igm.nsc.ru Eugenia A. Shalaeva. Geological Institute, Russian Academy of Sciences (GIN RAS), Pyzhevsky lane, 7, Moscow, 119017 Russia; es-geo@mail.ru

Vladimir G. Trifonov. Geological Institute of the Russian Academy of Sciences, Pyzhevsky per., 7, Moscow, 119017 Russia; trifonov@ginras.ru

Keywords: palynology; molluscs; fishes; mammals; Early-Middle Pleistocene; southern Caucasus

Submission: 16 August 2018. Acceptance: 5 April 2019.

\section{INTRODUCTION}

The Quaternary terrestrial biotic record of north-western Armenia is crucial for stratigraphy and correlations, and for understanding the development of Pleistocene biota under conditions of fluctuating climate, volcanic activity, and general neotectonic uplift of the Lesser Caucasus. Sedimentary filling of the depositional basins along the Akhuryan valley in Armenia are under study for a long time. The successive Ani and Arapi formations are traditionally recognised in the Shirak basin (Sayadyan, 1972). According to the paleontological and paleomagnetic data, the two formations correspond to late Early Pleistocene (the Ani Formation, Fm) and earliest Middle Pleistocene (Arapi Fm) (Sayadyan, 2009; Shalaeva et al., 2019).

Recent study of stratigraphy and neotectonics of NW Armeina based on several reference sections (Shalaeva et al., 2019) brought new diverse paleontological materials. In this contribution we specifically focus on the biotic record of the Ani and Arapi deposits. Fossils were analysed from sections Voghji and Haykavan (Ani unit, palynology, molluscs), Lusaghbyur and Haykadzor (Arapi unit, molluscs, fishes, amphibians, and mammals), and Krasar (Kurtan unit, palynology, mammals) (Figures 1-2). The data on palynology and molluscs are reviewed on the level of assemblages. The for- mal paleontological description of vertebrates is given separately.

The general aim of the paper is accurate documentation of the new paleontological record of late Early and early Middle Pleistocene of western Armenia as a basis for regional stratigraphy, history of climate and environment, and biogeographic connections in the broad Ponto-Caspian region, and for refining the mammalian biochronology of western Asia.

Our research is backed by important results of the previous studies, especially in palynology and fossil mammals. Palynological study of the lacustrine-fluviatile deposits of the Shirak Depression was first conducted by Sayadyan $(1972,2009)$ and Zaikina et al. (1969a, b). The deposits of substantially clayey Ani Fm record the main period of the development of the Shirak Paleolake. The study of these deposits showed a cyclic change of vegetation in the Ani time from forest-steppe phase through a steppe period to a well expressed forested phase at the top of the formation (Sayadyan, 1972). Data on Pleistocene diatom assemblages of the Shirak Depression was obtained from the lacustrine diatomaceous deposits of the Ani unit in the sections of Arapi and the Marmashen borehole 6 (Zaikina et al., 1969a, b). Additional diatom materials were recently studied in the Ani sections of Haykavan (lower part) and Arapi deposits of the 


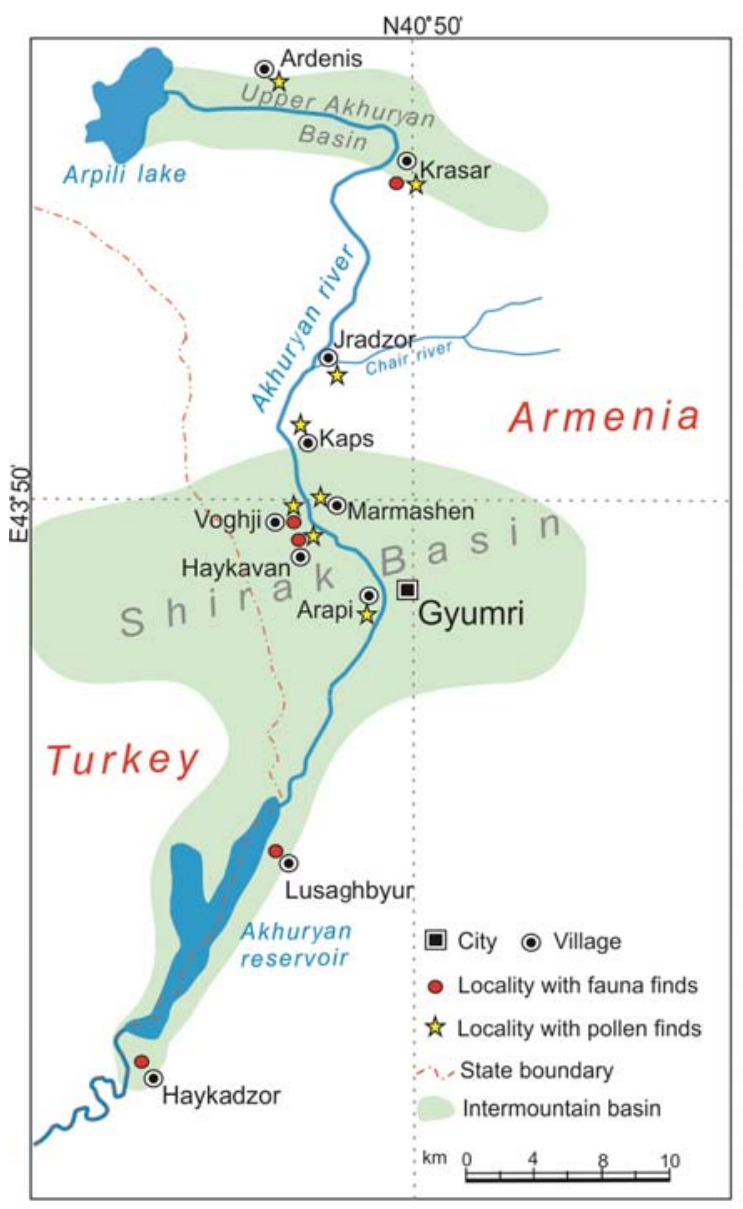

FIGURE 1. Schematic map showing the position of the studied sections.

Haykadzor section (beds 6-7) (Shalaeva et al., 2019). The general revealed trend is from assemblages with higher representation of planktonic forms in lower parts of the Ani Fm towards associations with growing role of bottom and littoral forms higher in the Ani sequences and in the Arapi Fm. This picture supports a concept of a shallowing of the Pleistocene Shirak Lake (Sayadyan, 2009) from late Early to early Middle Pleistocene.

The fluviatile deposits of the Arapi formation in the Shirak Basin of western Armenia yielded a large mammal assemblage, with the elephant Mammuthus trogontherii (Pohlig, 1885) and other forms, defined as the Leninakan (later, Gyumri) faunal complex (Avakyan, 1959) correlated to late Middle Pleistocene (Sayadyan, 1970, 2009; Alekseeva, 1977). The remains of Quaternary small mammals from the same fluviatile formation in western Armenia were studied by Melik-Adamyan and Agadjanyan (Agadjanyan, Melik-Adamyan, 1985; Melik-Adamyan, 1985, 1994, 2003, 2004).
The composition of this fauna with Mimomys intermedius, advanced Prolagurus pannonicus, and basal Terricola clearly indicated an older, early Middle Pleistocene age of the Gyumri assemblage (Agadjanyan, Melik-Adamyan, 1985; MelikAdamyan, 2004). Likewise, Forsten (1999) based on the morphology of horse remains from the Leninakan assemblage questioned the original age estimations as too late "for such a large stenonid horse" and argued for an early Middle Pleistocene age. She also rejected an assignment of these horses by Alexeeva (1977) to caballoid froms (Forsten, 1999). The additional age control was provided by the geochronology of the Leninakan tuffs covering or interfingering with Arapi deposits yielding dates in the range of $0.65-0.7 \mathrm{Ma}$ (MelikAdamyan, 2016; Shalaeva et al., 2019) and normal polarity (Brunhes Chron) of these deposits (Sayadyan, 2009; Trifonov et al., 2017; Shalaeva et al., 2019). Recently small mammals of the Gyumri appearance were found in the Krasar (bed 2) section in Upper Akhuryan basin of western Armenia (Trifonov et al., 2016; Tesakov, 2016). In 2015-2016 the relatively abundant association of small mammals was recovered from the Arapi deposits near the village of Haykadzor, in bed 4 of the Haykadzor section (Shalaeva et al., 2019).

\section{GEOLOGICAL SETTING}

Early and early Middle Pleistocene deposits fill the Upper Akhuryan and more southern Shirak basins (Figure 1). The latter extends to the adjacent part of North-Eastern Turkey. These deposits are differentiated into the Karakhach, Ani, and Arapi sedimentary units (formations) in the Shirak Basin (Sayadyan, 2009; Trifonov et al., 2017). In the northern margin of the Shirak Basin, the Lower Pleistocene Karakhach unit occupies the highest topographic position. The $6 \mathrm{~m}$ thick analog of Ani and Arapi units (Kurtan unit) is incised into the upper terrace composed by the Karakhach unit near the Kaps village (Trifonov et al., 2017). The surface of the Kurtan unit terrace is $60-70 \mathrm{~m}$ lower than the Karakhach unit terrace. Just to the south, the Ani unit thickness abruptly increases on the WE-trending Kaps flexure-fault zone (Trifonov et al., 2017) and reaches $137 \mathrm{~m}$ in the northern Shirak Basin, in the borehole 6 near the Marmashen village (Sayadyan, 2009). The Arapi unit is incised into the Ani unit terrace, and the Arapi unit surface is situated ca. $50 \mathrm{~m}$ lower than the Ani unit terrace (Trifonov et al., 2017). In the central Shirak Basin, the Karakhach unit thins out, and the Ani unit covers the basaltic trachyandesites with the K/Ar and 


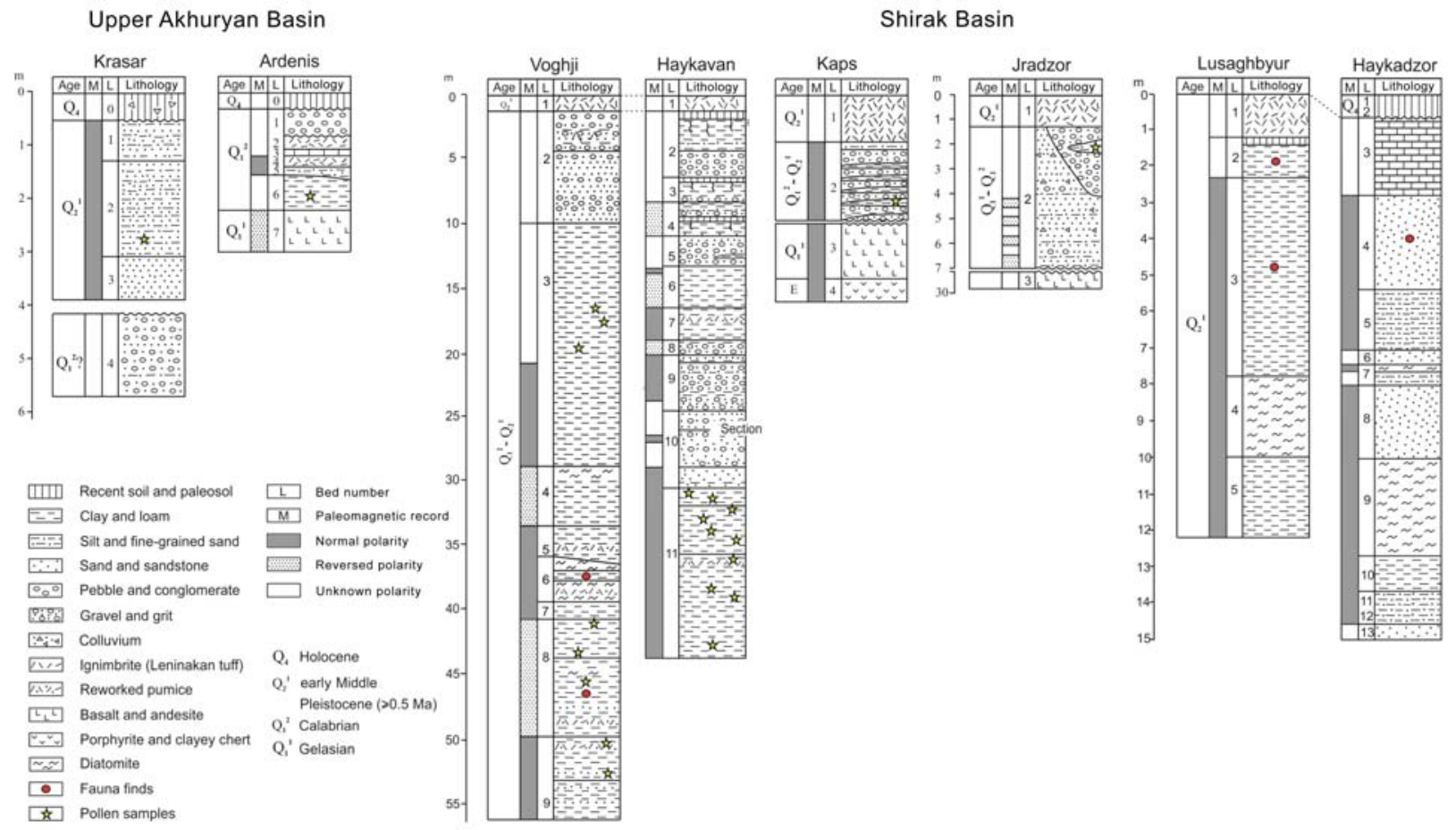

FIGURE 2. Main studied sections of Quaternary deposits in north-western Armenia (modified after Shalaeva et al., 2019).

${ }^{40} \mathrm{Ar} /{ }^{39} \mathrm{Ar}$ dates of $2.0-2.3 \mathrm{Ma}$ that underlie the Karakhach unit in the northern margin of the basin (Ritz et al., 2016; Trifonov et al., 2017; Shalaeva et al., 2019). Farther to the south, the Arapi unit covers the Ani unit in the Lusaghbyur locality. In this section deformed by a fault, the Ani deposits are exposed in the diapir piercing the Arapi sequence (Shalaeva et al., 2019). In the southern margin of the basin, in the section of Haykadzor, the Arapi unit overlies Early Pliocene basaltic andesites (the $\mathrm{K} / \mathrm{Ar}$ dates $5.60 \pm 0.15 \mathrm{Ma}$ to $4.26 \pm 0.12 \mathrm{Ma}$ ) (Shalaeva et al., 2019). Therefore, the Karakhach unit is older than the Ani one, and the Arapi unit is the youngest.

The deposits that are attributed to the Karakhach unit in the Shirak Basin are correlated with the unit stratotype in the Karakhach quarry in the south-western Lori Basin, where the unit is dated to 1.9-1.7 Ma by the SIMS $238 \mathrm{U} / 206 \mathrm{~Pb}$ method with using volcanic zircons and by the remanent magnetic polarity analysis (Presnyakov et al., 2012; Trifonov et al., 2016). These deposits are characterised by similar lithology (mountain alluvium), archaeological finds (earliest Paleolithic), and magnetic polarity with a normal zone in the lower part (Olduvai Subchron) and a reverse one in the upper part (the lowest part of Upper Matuyama Chron), although the lower part of the unit with nor- mal magnetic polarity is reduced in the Shirak Basin.

The detailed description of geological setting of late Early and early Middle Pleistocene deposits of the Shirak Basin is given in the paper of Shalaeva et al. (2019). Both Ani and Arapi units are mainly composed of lacustrine deposits in the lower and middle parts and of the fluviatile sediments in the uppermost part. The lower part of the Ani unit shows alternating beds with reverse and normal magnetic polarity in the Voghji and Haykavan sections (Figure 2). The magnetization of the upper part of the Ani unit was examined only in the Voghji section and showed normal polarity. All studied Arapi unit sections show normal magnetic polarity. The Arapi unit is covered by trachydacitic ignimbrites (so called Leninakan tuffs) with ${ }^{40} \mathrm{Ar} /$ ${ }^{39} \mathrm{Ar}$ date of $0.65 \pm 0.04 \mathrm{Ma}$ (Gevorgyan et al., 2018) and K/Ar dates $0.68 \pm 0.05 \mathrm{Ma}$ (Shalaeva et al., 2019). Melik-Adamyan (2003), however, reported the upper layers of the Arapi unit covering this tuff near the Gyumri Airport. The molluscan association of the Arapi unit contains mostly Recent limnic species contrary to the Ani mollusc fauna represented mainly by extinct fresh water species (Shalaeva et al., 2019). The combination of these data gives a possibility to date the Ani unit within the time interval ca. 1.5-0.8 (?0.75) Ma and 
the Arapi unit at $0.70-0.65 \mathrm{Ma}$. The paleontological data presented below support these estimates.

In the Upper Akhuryan Basin, the late Early and early Middle Pleistocene deposits form the Kurtan unit (Trifonov et al., 2016). Its stratotype is situated in the south-eastern Lori Basin, where the Kurtan unit overlies reversely magnetised ash and pumice layers. The pumice fills a small depression incised into the eroded surface of basaltic trachyandesites with $\mathrm{K} / \mathrm{Ar}$ date $2.08 \pm 0.10$ (Trifonov et al., 2016). The SIMS U-Pb and ${ }^{39} \mathrm{Ar} / 40 \mathrm{Ar}$ dates of the pumice are $1.495 \pm 0.021 \mathrm{Ma}$ and $1.49 \pm$ $0.01 \mathrm{Ma}$, correspondingly, and the SIMS U-Pb date of the ash is $1.432 \pm 0.028 \mathrm{Ma}$ (Presnyakov et al., 2012). The lower part of the Kurtan unit shows reverse magnetic polarity with a short interval of normal polarity (Jaramillo Subchron) and the upper part of the unit shows normal magnetic polarity (Trifonov et al., 2016, 2017). The fragmentary left humerus of southern elephant Archidiskodon ex gr. meridionalis (Nesti, 1825) was found in the lower part of the unit. The Krasar section in the Upper Akhuryan Basin (Figure 2) belongs to the upper part of the Kurtan unit. The section deposits show normal magnetic polarity and contain remains of mammals. Combining the chronological information from large and small mammals and the paleomagnetic data, an early Middle Pleistocene age of the section seems to be the most plausible (Trifonov et al., 2016).

\section{MATERIALS AND METHODS}

Palynological studies were based on more than 200 samples from 16 sections. The revealed concentration of palynomorphs strongly varied. The highest content of pollen (80-322 grains) was found in clayey deposits of the Ani Fm in sections of Ardenis, Marmashen, Arapi, Haykavan, and Voghji. In silty, gravely and sandy, and diatomaceous deposits in the sections of Lusaghbyur, Haykadzor, and Gyumry (Airport) we found only single pollen grains or none at all. Some samples in loamy deposits in the youngest sections of Haykadzor, Kaps, and Jradzor yielded up to 100 grains.

Preparation of samples was carried out according to the modified separation method. It includes a treatment with $10 \%$ hydrochloric acid $(\mathrm{HCl})$ to remove carbonates, washing samples by adding distilled water until neutral reaction, processing samples with hot $10 \%$ disodium phosphate $\left(\mathrm{Na}_{2} \mathrm{HPO}_{4}\right)$, removing clay particles by washing out the sediment with distilled water, separation of the resulting precipitate in heavy liquid potassium tetraiodocadmate $\left(\mathrm{K}_{2}\left[\mathrm{Cdl}_{4}\right]\right)$ with a density of 2.25 to extract fossil palynomorphs. In addition the sediment was treated with hydrofluoric acid (HF). Palynological preparations were studied under Motic VA 400 optical microscope equipped with Moticam 2300 camera, at magnification of $\times 400$. Pollen diagrams were compiled using Tilia 2.0.41 software.

The molluscan and microvertebrate remains were collected in the field in 2013-2016 by the field team of the Geological Institute of the Russian Academy of Sciences headed by V. Trifonov in collaboration with geologists from the Institute of Geological Sciences of the National Academy of Sciences of Republic of Armenia. The standard technique of dry screening with the use of 0.7 and $1.0 \mathrm{~mm}$ mesh size sieves was utilized. The microvertebrate concentrate was separated in several size fractions and manually sorted in the laboratory. The geographic positions of the studied sections are given in captions to Figure 1.

Geographic positions of the studied sections: Ardenis $\left(41^{\circ} 03^{\prime} 54.78^{\prime \prime} \mathrm{N} 43^{\circ} 42^{\prime} 43.14^{\prime \prime} \mathrm{E}\right)$, Krasar $\left(41^{\circ} 00^{\prime} 45.18^{\prime \prime} \mathrm{N} \quad 43^{\circ} 49^{\prime} 52.32^{\prime \prime} \mathrm{E}\right), \quad$ Jradzor $\left(40^{\circ} 54^{\prime} 29.80^{\prime \prime} \mathrm{N} \quad 43^{\circ} 46^{\prime} 16.59^{\prime \prime} \mathrm{E}\right), \quad$ Kaps $\left(40^{\circ} 52^{\prime} 22.33^{\prime \prime} \mathrm{N} \quad 43^{\circ} 45^{\prime} 02.13^{\prime \prime} \mathrm{E}\right), \quad$ Marmashen $\left(40^{\circ} 50^{\prime} 26.26^{\prime \prime} \mathrm{N} \quad 43^{\circ} 45^{\prime} 30.23^{\prime \prime} \mathrm{E}\right), \quad$ Voghji $\left(40^{\circ} 49^{\prime} 34.63^{\prime \prime} \mathrm{N} 43^{\circ} 44^{\prime} 44.16^{\prime \prime} \mathrm{E}\right)$, Haykavan $\left(40^{\circ} 48^{\prime}\right.$ $\left.50.51^{\prime \prime} \mathrm{N} \quad 43^{\circ} 44^{\prime} 54.64^{\prime \prime} \mathrm{E}\right)$, Arapi $\left(40^{\circ} 46^{\prime} 26.58^{\prime \prime} \mathrm{N}\right.$ $\left.43^{\circ} 48^{\prime} 22.14^{\prime \prime} \mathrm{E}\right), \quad$ Lusaghbyur $\quad\left(40^{\circ} 38^{\prime} 38.22^{\prime \prime} \mathrm{N}\right.$ $\left.43^{\circ} 44^{\prime} 30.42^{\prime \prime} \mathrm{E}\right), \quad$ Haykadzor $\quad\left(40^{\circ} 32^{\prime} 16.02^{\prime \prime} \mathrm{N}\right.$ $\left.43^{\circ} 39^{\prime} 21.13^{\prime \prime} \mathrm{E}\right)$.

The terminology of the fish pharyngeal teeth follows the system of Rutte (1962) partially modified by Sytchevskaya (1986). The morphological terminology of anuran bones is after Bolkay (1919). The terminology of equine premolar is according to Gromova (1949) and Eisenmann (1981). The terminology of arvicoline molars follows van der Meulen (1973) and Rabeder (1981). The terminology of arvicoline enamel differentiation patterns and indexes follows Heinrich (1982). All measurements are in $\mathrm{mm}$.

The violin diagram was produced using the Past software v.3.19 (Hammer et al., 2001).

The authors of this paper contributed to the study of small mammals and biochronology (A.S. Tesakov), palynology (A.N. Simakova), molluscs (P.D. Frolov), fishes (E.K. Sytchevskaya), amphibians (E.V. Syromyatnikova), large mammals (I.V. Foronova), and geological setting (E.A. Shalaeva and V.G. Trifonov).

Paleontological materials described in this paper are preserved in the Geological Institute of the Russian Academy of Sciences, GIN (GIN-1141, 
1142, 1172: molluscs, amphibians, small mammals) and Paleontological Institute of the Russian Academy of Sciences, PIN (PIN-5595: fishes) in Moscow.

\section{BIOTIC RECORD}

\section{Palynology}

In our work we studied the palynology of two sections of lacustrine deposits of the Ani Fm, Voghji and Haykavan and several sections exposing younger deposits of the Arapi Formation. According to the paleomagnetic data, the Ani Fm is dated to the late Early and earliest Middle Pleistocene (Shalaeva et al., 2019). Palynological data were obtained from eight sections (Figure 3 ) of the Early-early Middle Pleistocene units of Shirak and Upper Akhuryan basins. The oldest spectra came from a loam bed underlain by basaltic andesites with $\mathrm{K}-\mathrm{Ar}$ date of $2.00 \pm 0.10 \mathrm{Ma}$ (Trifonov et al., 2016) in the quarry southwest of the Ardenis village in the Upper Akhuryan Basin (Figure 2). The spectrum is dominated by coniferous pollen $(90 \%)$ mainly represented by pine, including Pinus sect. Strobus, Pinus cf. excelsa, and birch (16\%). Also encountered is the pollen of Picea, Podocarpus. Also present are single grains of Quercus, Tilia, Salix, Ericales, Chenopodiaceae, and Filicales. These data indicate the widespread pine-birch forests.

In the Shirak Basin, the oldest palynological records came from the dark olive-coloured clays of the Ani $\mathrm{Fm}$ in the section near the Marmashen monastery (Shalaeva et al., 2019; Figure 4) The 65 $\mathrm{m}$ thick clays overlie basaltic andesite outcropping in the channel of Akhuryan River. Another location of an older record is the section exposed in the roadcut near the village of Arapi (Shalaeva et al., 2019; Figure 4). Clays in Marmashen show a spectrum dominated by pollen of trees as Pinus, Picea (98\%), with additions of pollen of Cedrus, Podocarpus, and Abies. These data evidence the widespread pine-spruce forests gradually replaced by pine forests with rare occurrence of Picea and Tsuga (olive-coloured clays of the Arapi roadcut section) interpreted as the onset of aridisation. Pollen data on these three sections indicate moist temperate continental climatic period possibly mathching climatically based stratons (climatoliths) 11 or 13 of regional climatical periodisation defined by Sayadyan (2009).

The overlying sediments of the Ani Formation in sections of Haykavan and Voghji (Figure 2) contain clayey diatomites, dark-brown clays with abun- dant molluscan remains strongly dominated by Dreissena and interlayers of volcanic material. The pollen spectra of the lower parts of the sections (Figures 2-4; Shalaeva et al., 2019) show a high share of Chenopodiaceae, Asteraceae, and Ephe$d r a$. The content of arboreal pollen amounts to 15$50 \%$. The spectra are specific in high diversity of conifers: Taxodium, Podocarpus, Tsuga canadensis, cf. Tsuga sieboldii, Tsuga aculeata, Tsuga diversifolia, Abies, Picea, Pinus, and broadleaved trees: Acer, Castenea, Carya, Juglandaceae, Moraceae, Carpinus, Fagaceae, Tilia, Ulmus, Liquidambar, Myrica, and Quercus. The spectra indicate a presence of altitudinal zonation manifested in the regular change of plant communities. The association of higher altitudinal zones is characterised by Sciadopitys, Podocarpus, Cedrus, Tsuga, Picea, and Abies. Lower belts were dominated by mixed pine and broad-leaved forests. The low elevations were covered by meadow-steppe vegetation in a relatively warm temperate climate. Lower parts of Haykavan and Voghji sections indicating an interval of predominant forest-steppe under conditions of semi-humid temperate climate we correlate with the climatolith 15 of the scheme elaborated by Sayadyan (2009).

The amount of pollen of grasses and shrubs (Chenopodiaceae, Asteraceae, Ephedra) increases upsection in Haykavan. At the same time the spectra show a decreasing amount of Picea and Pinus, and disappearance of Cedrus, Abies, Podocarpus, and Carya. The leaved trees and shrubs are represented by Ilex, Acer, Moraceae, Fagaceae, Lonicera, Salix, and Quercus. Also present are spores of freshwater algae Cosmarium and spores of Sphagnum. These indicate the presence of swampy areas that could possibly originate during the shallowing of the paleolake. Steppe vegetation expanded, and this stage can be correlated with climatolith 16 (semi-arid steppes and forest-steppe) of Sayadyan (2009). Similar spectra were obtained from the clays of the lower part of borehole 6 near the village of Marmashen, interpreted as the deposits of the 6th terrace of the Akhuryan River at the depth of 30-50 m (Zaikina et al., 1969).

The upper part of the Voghji section (Figure 2) documents an interval with increasing amount of pollen of Pinus and Tsuga. Deciduous trees are represented by the pollen of Castenea, Betula, Ulmus, and Quercus. The representation of Chenopodiaceae and Ephedra decreases. This is a period of expansion of coniferous forests (pine and spruce-tsuga) during colder and wet climatic conditions. The uppermost part of the Voghji section is 


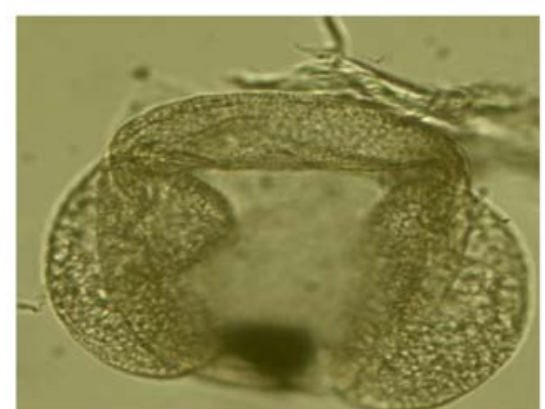

1

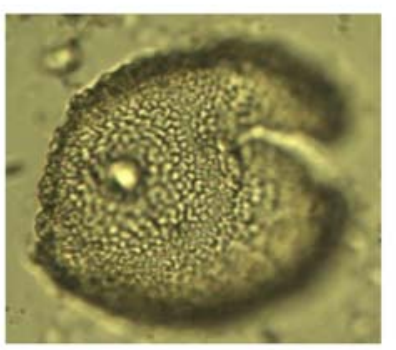

4

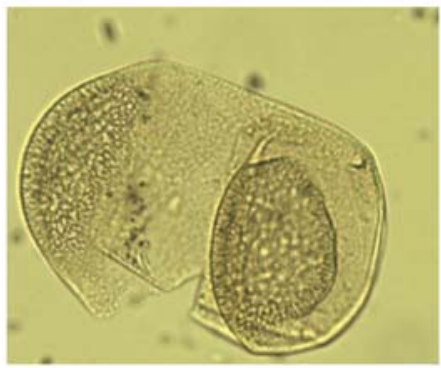

8

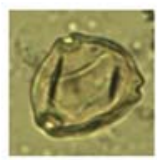

14

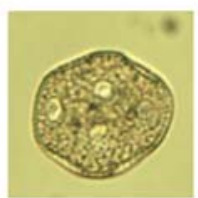

19

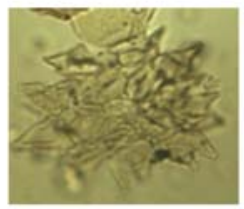

26

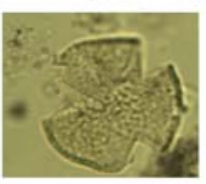

15

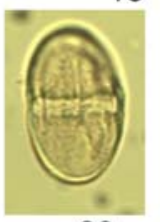

20

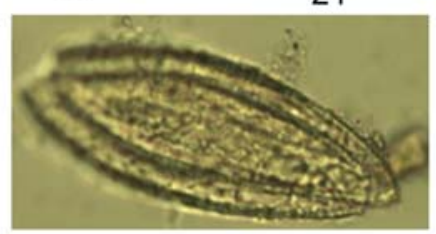

27

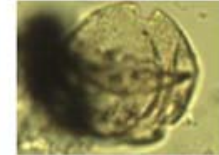

16

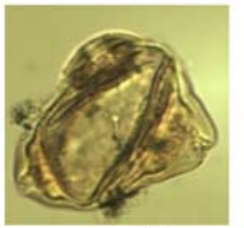

21
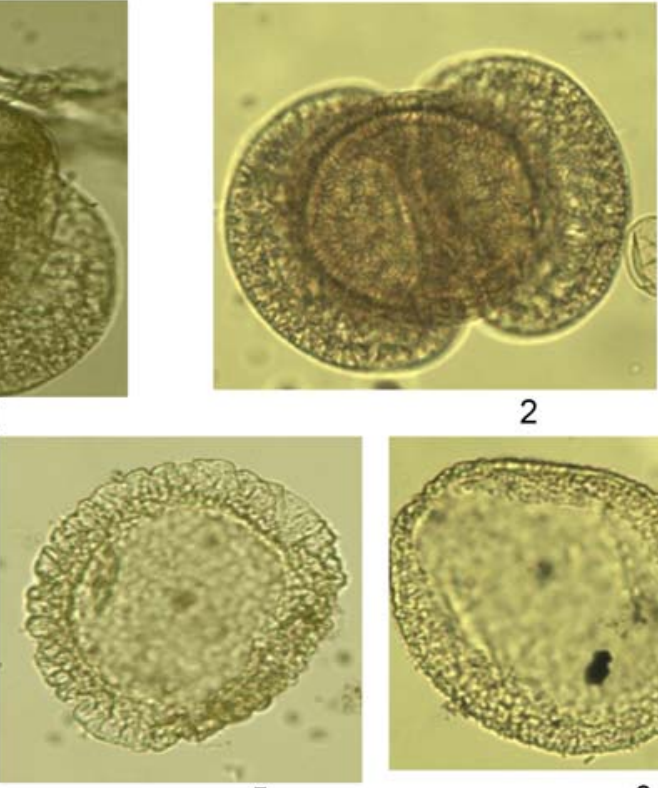

5

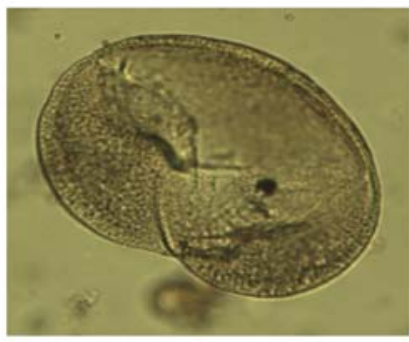

9

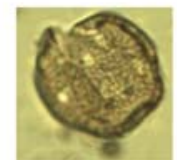

17

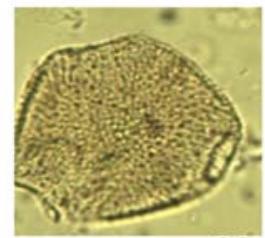

22

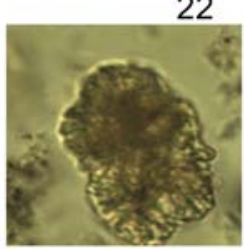

28
2

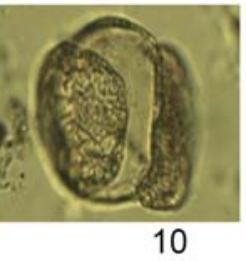

6

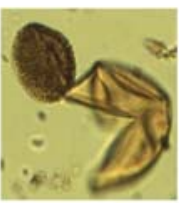

3

20 um

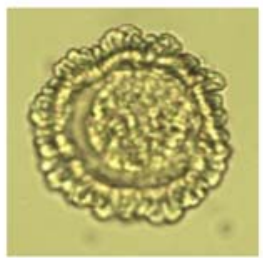

7

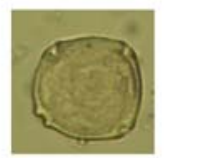

11
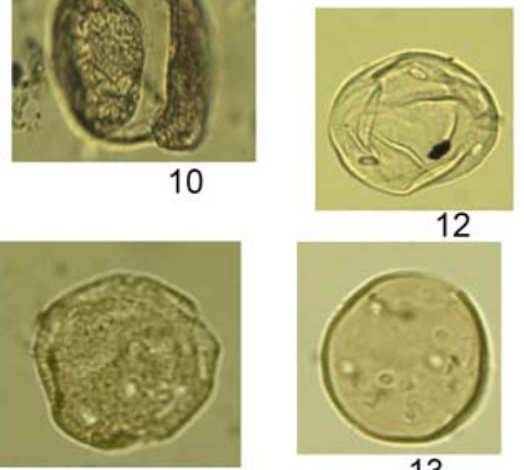

18

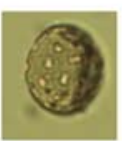

23

24
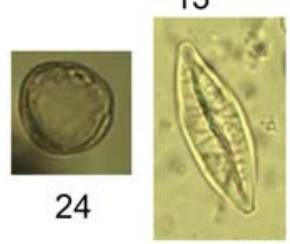

25

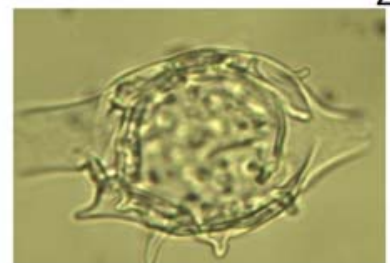

29

FIGURE 3. Characteristic palynomorphs of the Quaternary deposits of the Ani Formation, north-western Armenia. 1. Abies sp.; 2. Podocarpus sp.; 3. Taxodiaceae; 4. Tsuga canadensis; 5. Tsuga diversifolia; 6. Tsuga aculeata; 7 . Tsuga sieboldii; 8. Picea sect. Eupicea; 9. Picea sect. Omorica; 10. Pinus sp.; 11. Pterocarya aff. stenoptera; 12. Carya sp. 13. Juglans sp.; 14. Betula sp.; 15. Acer sp.; 16. Fagus sp.; 17. cf. Altingia; 18. Liquidambar sp.; 19. Caryophyllaceae; 20. Boraginaceae; 21. Onograceae; 22. Scabiosa sp.; 23. Chenopodiaceae; 24. Poaceae; 25. Ephedra sp.; 26. Pediastrum; 27. Spirogyra; 28. Botryococcus; 29. unidentified. 


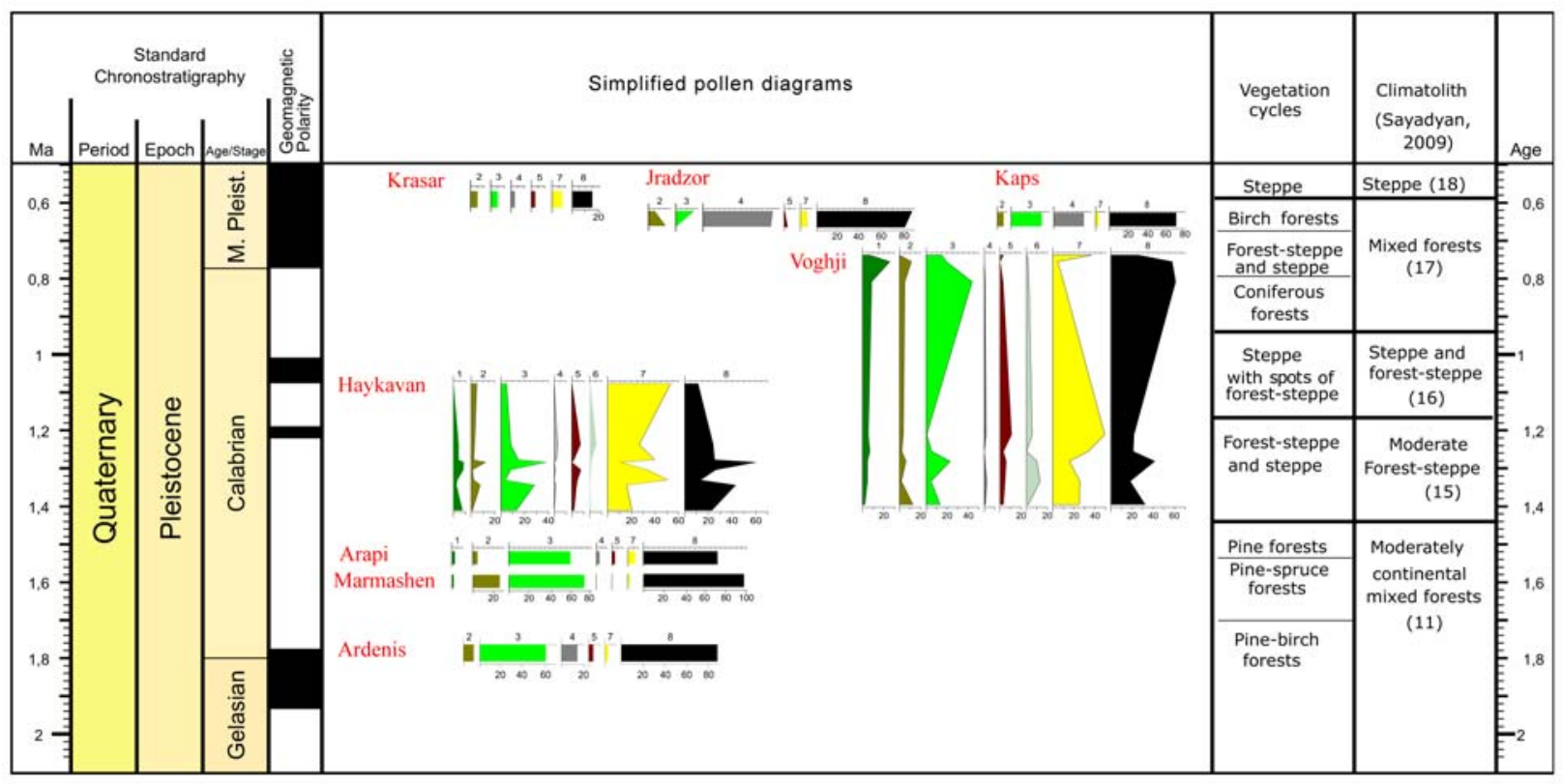

FIGURE 4. Palynological subdivision of the late Early - early Middle Quaternary deposits of north-western Armenia. Stratigraphic positions and ranges of the sequences are tentatively modeled based on data from Trifonov et al. (2016, 2017) and Shalaeva et al. (2019). I - Krasar; II - Jradzor (Shirak Province); III - Kaps; IV - Haykavan; V Voghji; VI - Arapi; VII - Marmashen; VIII - Ardenis; 1 - Podocarpus, Sciadopitys, Tsuga, Taxodium; 2 - Picea, Abies, Cedrus; 3 - Pinus, 4 - Betula, Salix, Alnus; 5 - broad-leaved trees; 6 - Ephedra, 7 - Artemisia, Chenopodiaceae; 8 - arboreal pollen realtive to total pollen sum.

characterised by an increase in grass pollen (Chenopodiaceae and Asteraceae) representative of the widespread steppe coenoses under dry and cool climate.

Palynological characteristics for the Arapi Formation were obtained from alluvial deposits capped by the Leninakan tuff on the northern side of the Shirak Depression, in sections Kaps and Jradzor (Figure 2). The spectra contain up to $75 \%$ of arboreal pollen (Pinus and Betula) indicating dominant pine-birch forests. These spectra lack exotics elements common for assemblages of the Ani Fm. The deposits of Kaps and Jradzor indicating humid and moderately continental climate can be compared with the climatolith 17 of Sayadyan (2009).

The youngest spectra of the Arapi Fm were obtained from the lacustrine-alluvial deposits of the Middle Pleistocene in the section of the Krasar (Upper Akhuryan Depression). Grass pollen (Asteraceae and Chenopodiaceae) dominates in the assemblage. Pollen of Pinus, Picea, Betula, and Ulmus are represented by single grains. The content of arboreal pollen is less than $20 \%$ of the pollen sum. These spectra indicate a predominance of meadow-steppe landscapes. According to palynological data, the deposits of Krasar can be correlated with the semiarid climatolith 18 and the upper lacustrine-alluvial complex of the Middle Pleistocene of the Shirak Basin (Sayadyan, 1972, 2009).

The presence of a significant number of arboreal species not common ("exotic") to the recent flora of the studied region (Figure 3 ) in the palynological spectra of the Ani Formation (Tsuga aculeata, Tsuga canadensis, Tsuga diversifolia, cf. Tsuga sieboldii, Podocarpus, Cedrus, Abies alba, Abies nordmanniana, Taxus, Liquidambar, Castanea, and Carya) indicate the ancient age of the lacustrine sediments of the Shirak and Upper Akhuryan depressions. A comparison with the palynological record of the neighbouring regions shows similar trends regardless of possible regional differences. The vegetation of the south and southeast Armenia in the second half of the early Pleistocene (1.41-0.94 Ma) had a mosaic structure combining mixed forests and open areas with steppe plant communities (Joannin et al., 2010; Scharrer, 2013). Palynological spectra of late Early Pleistocene in Georgia (early Chaudian) (Mchedlishvili, 1984, Chochieva, 1999; Shatilova, et al., 2011) are characterised by diverse and abundant Tsuga, as well as by the presence of Podocarpus and Pseudotsuga, which do not occur 
in younger sediments. The record of Azerbaijan also shows an expansion of forest vegetation edified by birch, alder, spruce and tsuga in late Early Pleistocene (0.95-0.77 Ma). Thus, the pollen spectra of the Ani Formation of northeastern Armenia reflect a common climatic trend in late Early Pleistocene of the southern Caucasus and the adjacent Caspian region (Zaikina et al., 1969a, b, Filippova, 1997; Shatilova, 1974; Joannin et al., 2010; Tagieva, 2011; Shatilova, et al., 2011; Scharrer, 2013). In general, the vegetation of Armenia during late Early Pleistocene had a mosaic structure and combined mixed forests and open areas with steppe vegetation. In colder stages, the meadow-steppe vegetation shows a predominance of Asteraceae, Chenopodiaceae, and Artemisia. Forests of that time were dominated mainly by coniferous trees Pinus, Tsuga, Abies, and Sciadopitys. In warmer periods the mountain slopes hosted sparse mesophilic forests with Quercus, Carpinus, Juglans, Ulmaceae, Picea, and Tsuga, and the open spaces were covered with herbaceous steppes.

At the beginning of the Middle Pleistocene, in contrast to Western Georgia (Shatilova et al., 2011), relict arboreal elements nearly disappeared in pollen spectra from the Shirak and Upper Akhuryan Basin (Sayadan, 1972, 2009; Trifonov et al., 2016) succeeded by assemblages with widespread forest-steppe and meadow-steppe vegetation.

\section{Molluscs}

Six molluscan associations from four sections were studied from deposits of the Ani and Arapi formations (Table 1). The fauna of the Ani Fm is represented by the assemblages of Voghji, Haykavan, and that of the diapir beds of Lusaghbyur. The assemblage derived from beds, which confine the diapir in the Lusaghbyur section, is regarded as malacologically transitional between faunas of Ani and Arapi formations. The assemblages sampled from the upper part of Lusaghbyur section and from Haykadzor section characterise the fauna of the Arapi Fm.

Aquatic molluscs from the Ani Fm (Figures 56 ) are co-dominated by extinct species Falsipyrgula sieversi and Dreissena diluvii. This association is similar to the fauna with sculptured pyrgulids previously described from the middle level of the Leninakan/Gyumri Lake deposits in northwestern Shirak Depression (Akramowski, 1956) and Early Pleistocene molluscan fauna from eastern Turkey (Vasilyan et al., 2014). The most representative of the Ani Fm assemblages is that from the section of
Voghji. It includes abundant hydrobiid gastropods and the fossil bivalve Dreissena diluvii.

The abundant hydrobiid shells are represented by the genera Shadinia Akramowski, 1976, and Falsipyrgula Radoman, 1973 (Figure 6).

The genus Shadinia contains three modern species: S. terpoghassiani (Shadin, 1952), S. akramowskii (Shadin, 1952), and S. bjniensis Bößneck, Walther and Neiber, 2016 (Zhadin, 1952; Glöer et al., 2016; Anistratenko et al., 2017). In our materials there are elongated shells reminiscent of S. terpoghassiani and more squat forms resembling S. cf. akramowskii. These shells differ from the modern species in more convex whorls. One of these forms, S. terpoghassiani, represents the modern species. It is possible that the other one will be later described as a new species.

Pyrgula-like shells are referred to the genus Falsipyrgula Radoman, 1973, following Schütt and Yildirim (1999). In his preceding works Schütt (1991, 1997) referred these shells to the genus Pyrgula. When describing the genus Falsipyrgula, Radoman (1973) noted the characters of soft body as the main distinction from the closely related Pyrgula, Diana, and Xestopyrgula; the shell structure showed very little differentiation. Anistratenko (2008), however, remarked that Falsipyrgula is characteristic in a clear keel above the suture. In our materials there are several forms of this genus: Falsipyrgula shadini (Akramowski, 1956), F. sieversi (Boettger, 1881), F. cf. shuetti Yildirim, 1999, and $F$. sp.

In the Voghji locality, shells of $F$. sieversi are the most numerous. They are quite variable as was noted by Akramowski (1956). Our material shows all transitional forms from shells nearly lacking a keel to the shells with a well-developed keel, with a gradual flattening of the whorls. Today F. sieversi occurs in the eastern region of Turkey (Yildirim, 1999).

Falsipyrgula shadini was described from a sand pit near Byurakn (formerly Gyullibulagh) village in the Shirak province of Armenia, $12 \mathrm{~km}$ north-west of Gyumri (Akramowski, 1956). The enclosing deposits obviously correspond to the Ani Formation. Another fossil record comes from the Yayladag site (Pasinler Basin, Turkey), which is correlated with late Early Pleistocene (Schütt, 1997; Schütt and Yildirim, 1999; Vasilyan et al., 2014).

Falsipyrgula shuetti was described from the eastern shore of Lake Beyşehir (Central Anatolia,Turkey). Since the authors found only empty 
TABLE 1. Molluscs from the late Early and early Middle Pleistocene localities of north-western Armenia.

\begin{tabular}{|c|c|c|c|c|c|c|}
\hline \multirow[b]{3}{*}{$\begin{array}{l}\text { Localities } \\
\text { Taxa }\end{array}$} & \multicolumn{6}{|c|}{ Formations } \\
\hline & \multicolumn{3}{|c|}{ Ani Formation } & \multirow{2}{*}{$\begin{array}{c}\text { ?transitional beds } \\
\text { Lusaghbyur } \\
\text { (member enclosing } \\
\text { diapir) }\end{array}$} & \multicolumn{2}{|c|}{ Arapi Formation } \\
\hline & Voghji & Haykavan & $\begin{array}{l}\text { Lusaghbyur } \\
\text { (diapir) }\end{array}$ & & $\begin{array}{l}\text { Lusaghbyur } \\
\text { (overthrust } \\
\text { wing) }\end{array}$ & Haykadzor \\
\hline Valvata piscinalis (Müller, 1774) & + & - & - & - & + & + \\
\hline $\begin{array}{l}\text { Valvata piscinalis cf. alpestris (Küster, } \\
\text { 1853) }\end{array}$ & - & + & - & + & - & - \\
\hline Valvata pulchella (Studer, 1820) & - & - & - & + & - & + \\
\hline Valvata cristata (Müller, 1774) & - & - & - & - & - & + \\
\hline $\begin{array}{l}\text { Shadinia cf. terpoghassiani (Shadin, } \\
\text { 1952) }\end{array}$ & + & - & - & - & - & - \\
\hline Shadinia spp. & + & - & - & - & - & - \\
\hline ? Pyrgorientalia sp. & + & - & - & - & - & - \\
\hline Falsipyrgula sieversi (Boettger 1881) & + & - & + & - & - & - \\
\hline Falsipyrgula shadini (Akramowski, 1956) & + & - & - & - & - & - \\
\hline Falsipyrgula cf. shuetti Yildirim, 1999 & + & - & - & - & - & - \\
\hline $\begin{array}{l}\text { Falsipyrgula cf. bakhtarana ? (Schütt et } \\
\text { Mansoorian, 1999) }\end{array}$ & + & - & - & - & - & - \\
\hline Falsipyrgula spp. & + & - & - & - & - & - \\
\hline Pseudamnicola spp. & + & - & - & + & - & + \\
\hline Bithynia sp. & - & + & + & + & - & + \\
\hline Succineidae indet. & - & - & - & - & - & + \\
\hline Lymnaea spp. & - & - & - & - & - & + \\
\hline Planorbis planorbis (Linnaeus, 1758) & - & - & - & - & - & + \\
\hline Anisus spirorbis (Linnaeus, 1758) & - & - & - & - & - & + \\
\hline Gyraulus spp. & - & - & - & - & - & + \\
\hline Armiger crista (Linnaeus, 1758) & - & - & - & - & - & + \\
\hline $\begin{array}{l}\text { Pisidium (Europisidium) cf. } \\
\text { tenuilineatum (Stelfox, 1918) }\end{array}$ & + & + & - & - & - & - \\
\hline $\begin{array}{l}\text { Pisidium (Neopisidium) moitessierianum } \\
\text { (Paladilhe, 1866) }\end{array}$ & - & - & - & + & - & + \\
\hline $\begin{array}{l}\text { Pisidium (Odhneripisidium) stewarti } \\
\text { (Preston, 1909) }\end{array}$ & - & - & - & - & - & + \\
\hline $\begin{array}{l}\text { Euglesa (Euglesa) casertana ponderosa } \\
\text { (Stelfox, 1918) }\end{array}$ & + & - & - & + & + & + \\
\hline $\begin{array}{l}\text { Euglesa (Cingulipisidium) nitida (Jenyns, } \\
\text { 1832) }\end{array}$ & - & - & - & + & + & + \\
\hline $\begin{array}{l}\text { Euglesa (Cyclocalyx) obtusale } \\
\text { (Lamarck, 1818) }\end{array}$ & - & - & - & - & + & + \\
\hline $\begin{array}{l}\text { Euglesa (Henslowiana) henslowana } \\
\text { (Leach and Sheppard, 1823) }\end{array}$ & - & - & - & - & - & + \\
\hline Dreissena diluvii (Abich, 1859) & + & + & + & - & - & + \\
\hline
\end{tabular}

shells, it is possible that this is a Holocene species (Schütt and Yildirim, 1999; Yildirim et al., 2006).

Our material also presents a form resembling Falsipyrgula cf. bakhtarana Schütt and Mansoorian, 1999, originally described from Iran (Schütt and Mansoorian, 1999).
The Voghi assemblage also includes a characteristic small bivalve (Figure 5.3), Pisidium cf. tenuilineatum (Stelfox, 1918). Compared to the extant species, absent in the fauna of Armenia but occurring in western Transcaucasia, the fossil form shows more pronounced and sparse ribs on the 


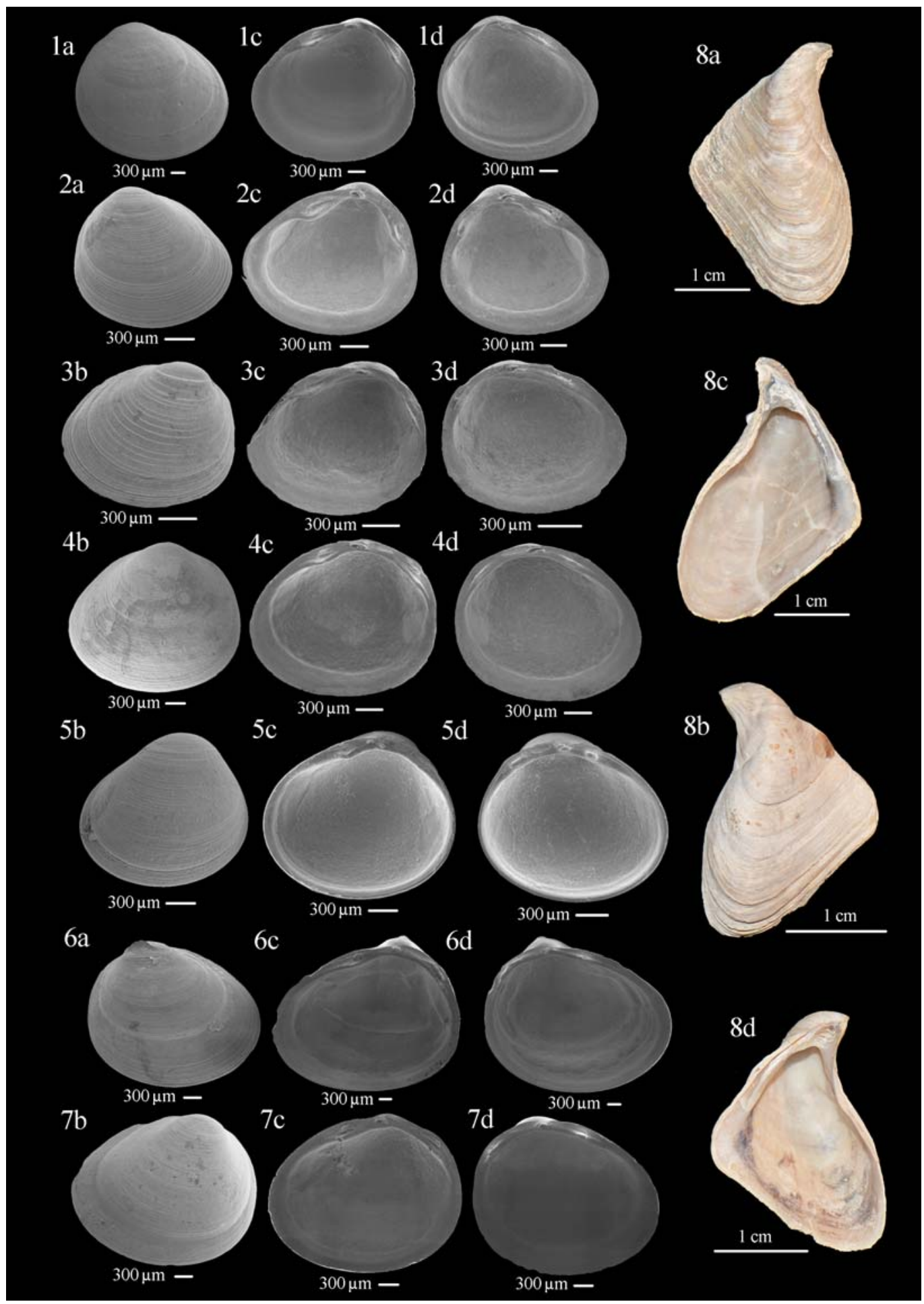

FIGURE 5. Bivalve molluscs from the late Early and early Middle Quaternary deposits of north-western Armenia. 1. Pisidium (Odhneripisidium) stewarti, GIN-1142/151; 2. Pisidium (Neopisidium) moitessierianum, GIN-1142/152; 3. Pisidium (Europisidium) cf. tenuilineatum, GIN-1172/19; 4. Euglesa (Cingulipisidium) nitida, GIN-1142/154; 5. Euglesa (Cyclocalyx) obtusale, GIN-1142/155; 6. Euglesa (Henslowiana) henslowana, GIN-1142/156; 7. Euglesa (Euglesa) casertana ponderosa, GIN-1142/157; 8. Dreissena diluvii, GIN-1172/20. 1-2, 4-7 - Haykadzor, bed 4; 3 - Voghji, bed $8 ; 8$ - Voghji, bed 6 . a, outer surface of the right valve; b, outer surface of the left valve; $c$, inner surface of the right valve; $d$, inner surface of the left valve. 


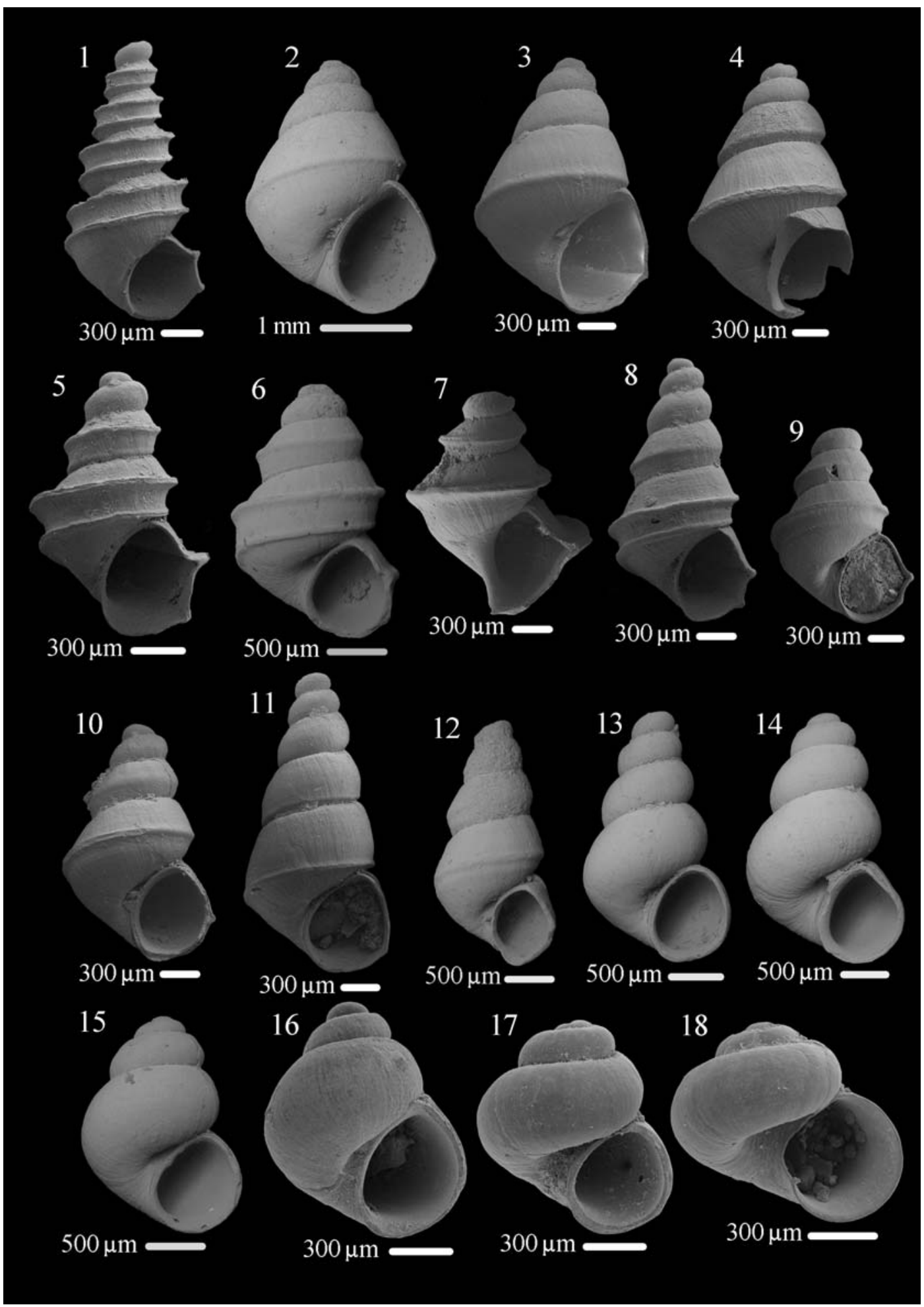

FIGURE 6. Gastropods from the late Early Quaternary deposits of north-western Armenia. 1. ?Pyrgorientalia sp., GIN-1172/1; 2-4. Falsipyrgula sieversi, GIN-1172/2-4; 5. Falsipyrgula shadini, GIN-1172/5; 6. Falsipyrgula cf. shuetti, GIN-1172/6; 7. ?Falsipyrgula cf. bakhtarana, GIN-1172/7; 8. Falsipyrgula sp. 1, GIN-1172/8; 9. Falsipyrgula sp. 2 , GIN-1172/9; 10. Falsipyrgula sp. 3, GIN-1172/10; 11. Falsipyrgula sp. 4, GIN-1172/11; 12. Shadinia cf. terpoghassiani (Shadin, 1952), GIN-1172/12; 13. Shadinia sp. 1, GIN-1172/13; 14. Shadinia sp. 2, GIN-1172/14; 15. Pseudamnicola sp. 1, GIN-1172/15; 16. Pseudamnicola sp. 2, GIN-1172/16; 17. Pseudamnicola sp. 3, GIN-1172/17; 18. Pseudamnicola sp. 4, GIN-1172/18. 1-18 - Voghji, bed 8. 
outer surface of the shell, and an additional delimitation of the umbo. The extant form is completely devoid of ribs on the outer surface of the shell.

Two other Ani Fm molluscan associations from Haykavan and the diapir of the Lusaghpyur are more species poor but reliably correlated with the Voghji fauna by co-ocurring $P$. cf. tenuilineatum (Haykavan) and F. sieversi (diapir of Lusaghbyur).

According to the composition of molluscan fauna, the beds which confine the diapir in the Lusaghbyur section may span the uppermost part of the Ani Fm and contain a transitional assemblage corresponding to a reorganization time of the malacofauna of Ani and Arapi formations. The presence of Valvata piscinalis cf. alpestris and Bithynia sp. is similar with the Haykavan fauna, and the composition of bivalve molluscs is close to that of the Haykadzor assemblage.

Molluscs of the Arapi Fm are characterised by modern limnophilic freshwater species with abundant and diverse sphaeriid bivalves (Figure 5). The most representative Arapi malacofauna is studied in the Haykadzor section. All species in this association, except Dreissena diluvii, are extant. Euglesa obtusale and E. nitida are known from Pleistocene of Turkey (Schütt, 1991, 1997). Pisidium stewarti, P. moitessierianum, and Euglesa henslowana have not been previously known in the Caucasus, Transcaucasia, or Anatolia. Other species are known from Transcaucasia and/or from the Near East. The typical feature of this fauna is its abundant and diverse freshwater pulmonate gastropods (Lymnaedae, Planorbidae). The Arapi fauna of the overthrust part of the Lusaghbyur section features the characteristic sphaeriid assemblage but lacks pulmonate gastropods.

The succession of Ani (Voghji) and Arapi (Haykadzor) mollusc faunas shows the transition of hydrobiid-dreissenid dominated fauna of the large and relatively deep freshwater Ani-time lake to the assemblage combining sphaeriid bivalves and pulmonat gastropods indicating the conditions of a large freshwater lake with shallow, overgrown areas with silty bottom in the Arapi time. The Ani assemblage contains several extinct forms (Shadinia spp., Dreissena diluvii), whereas the Arapi assemblage includes mostly extant species (except $D$. diluvii) and resembles the modern type lacustrine malacofauna of Armenia. It is yet to be established which of the malacological distinctions between Ani and Arapi are controlled by chronological or/and environmental/facies factors but a more modern appearance of the Arapi malacofauna (prevailing modern species) supports a younger, early Middle Pleistocene age of this formation.

\section{Vertebrates}

Fishes, amphibians, and mammals were found in the sections of the Arapi Fm (Table 2).

Remains of Pleistocene fishes from the southern part of the Shirak Basin in western Armenia were obtained from two localities of the Arapi Fm: Lusaghbyur, bed 2, and Haykadzor, bed 4 (Figure 2 ). Fishes are represented by scattered fragments of the skull bones and isolated pharyngeal teeth. Judging from the mode of preservation, the bones were buried near the site of fish death and underwent significant maceration.

The herpetofaunal remains are relatively scarce and represented by the two amphibian taxa: Bufotes viridis s. I. and Rana sp. recorded in microvertebrate material from Haykadzor, bed 2 . The modern herpetofauna of Armenia is highly diverse and includes seven amphibian and 51 reptilian species (Tadevosyan, 2004-2009; Arakelyan et al., 2011). The fossil herpetofauna of this region is poorly known and represented only by a few records, mostly from the Plio-Pleistocene. Among them, amphibians are represented by Bufo sp. and Pelophylax cf. ridibundus from the early Pliocene of Nurnus (Melik-Adamyan et al., 1988). Pelophylax cf. ridibundus are also known from the Pliocene fauna of Jradzor (= Gelaysor, Ararat Province), and from the Early Pleistocene of Sisian (Vasilyan et al., 2009; Vasilyan and Carnevale, 2013) and Syunik (Palaeo-Vorotan) (Gabrielyan et al. 2004; Arakelyan et al., 2011). The remains of Bufotes viridis s. I. (as Bufotes variabilis) and Rana (as Rana macrocnemis) were previously mentioned only form the Upper Paleolithic of Aghitu-3 Cave (Kandel et al., 2017).

The fluviatile deposits of the Arapi formation in the Shirak Basin of western Armenia yielded a large mammal assemblage, with the elephant Mammuthus trogontherii and other forms, defined as the Leninakan (later, Gyumri) faunal complex (Avakyan, 1959) correlated to late Middle Pleistocene (Sayadyan, 1970, 2009; Alekseeva, 1977). The remains of Quaternary small mammals from the same fluviatile formation in western Armenia were studied by Melik-Adamyan and Agadjanyan (Agadjanyan, Melik-Adamyan, 1985; MelikAdamyan, 1985, 1994, 2003, 2004). The composition of this fauna with Mimomys intermedius, advanced Prolagurus pannonicus, and basal Terricola clearly indicated an older, early Middle Pleistocene age of the Gyumri assemblage (Agadjanyan, 
TABLE 2. Composition of early Middle Pleistocene vertebrates in faunas of north-western Armenia.

\begin{tabular}{|c|c|c|c|}
\hline \multirow[b]{2}{*}{ Taxa } & \multicolumn{3}{|c|}{ Localities } \\
\hline & Haykadzor & Lusaghbyur & Krasar \\
\hline \multicolumn{4}{|c|}{ Pisces } \\
\hline Telestes cf. souffia & + & + & - \\
\hline Pseudalburnus sp. & + & + & - \\
\hline Capoeta sp. & + & + & - \\
\hline \multicolumn{4}{|c|}{ Amphibia } \\
\hline Bufotes viridis sensu lato & + & - & - \\
\hline Rana sp. & + & - & - \\
\hline \multicolumn{4}{|c|}{ Mammalia } \\
\hline Equus cf. stenonis & - & + & - \\
\hline Sorex cf. runtonensis & + & - & - \\
\hline Neomys cf. hintoni & + & - & - \\
\hline Ochotona sp. & - & - & + \\
\hline Ellobius pomeli & + & - & + \\
\hline Mimomys intermedius & + & - & - \\
\hline Microtus ex gr. nutiensis & + & - & - \\
\hline Terricola sp. & - & - & + \\
\hline Prolagurus pannonicus transylvanicus & + & - & - \\
\hline
\end{tabular}

Melik-Adamyan, 1985; Melik-Adamyan, 2004). Likewise, Forsten (1999) based on the morphology of horse remains from the Leninakan assemblage questioned the original age estimations as too late "for such a large stenonid horse" and argued for an early Middle Pleistocene age. She also rejected an assignment of these horses by Alexeeva (1977) to caballoid froms (Forsten, 1999). The additional age control was provided by the geochronology of the Leninakan tuffs covering or interfingering with Arapi deposits yielding dates in the range of 0.650.7 Ma (Melik-Adamyan, 2016; Shalaeva et al., 2019) and normal polarity (Brunhes Chron) of these deposits (Sayadyan, 2009; Trifonov et al., 2017; Shalaeva et al., 2019). Recently small mammals of the Gyumri appearance were found in the Krasar (bed 2) section in Upper Akhuryan basin of western Armenia (Trifonov et al., 2016; Tesakov, 2016). In 2015-2016 the relatively abundant association of small mammals was recovered from the Arapi deposits near the village of Haykadzor, in bed 4 of the Haykadzor section (Shalaeva et al., 2019). This fauna contributes to the knowledge of biodiversity and refines the biostratigraphic position of the Gyumri faunal complex.

\section{SYSTEMATIC PALEONTOLOGY}

Order CYPRINIFORMES Bleeker, 1859 Family CYPRINIDAE Rafinesque, 1820

\section{Subfamily LEUCISCINAE Bonaparte, 1835} Genus TELESTES Bonaparte 1837 Telestes cf. souffia (Risso, 1826)

Figure 7.1

Material. Three pharyngeal teeth, coll. PIN 5595. Locality. Haykadzor and Lusaghbyur localities. Measurements. Pharyngeal teeth of main row range in height from 4.0 to $4.5 \mathrm{~mm}$.

Description. Teeth of the main row are slender, narrow, straight; hook at the apex with a tip directed at right angle to the tooth axis. Anterior margin of the crown is oblique and serrate (bearing up to five serrations), the abdomen rounded, with a slight anterior compression at the neck region (Figure 7.1). In general, the teeth are similar to those from the presumably Pliocene locality Gelaysor (Jradzor) of the Ararat Depression (Vasilyan, 2008a, p. 116. fig. 3; Vasilyan and Carnevale, 2013) and to the teeth of the recent Telestes souffia (Risso, 1826).

Comments. Recent population area of Telestes souffia (Risso, 1826) is confined to European part of the Mediterranean basin and does not extend eastwards of the Tissa River basin in Romania and Ukraine. The species inhabits fresh waters with unstable flow regime and rocky bottom. The above described fossils, similar to modern representatives of this species, indicate a wider range of its close relatives in the Pleistocene. 


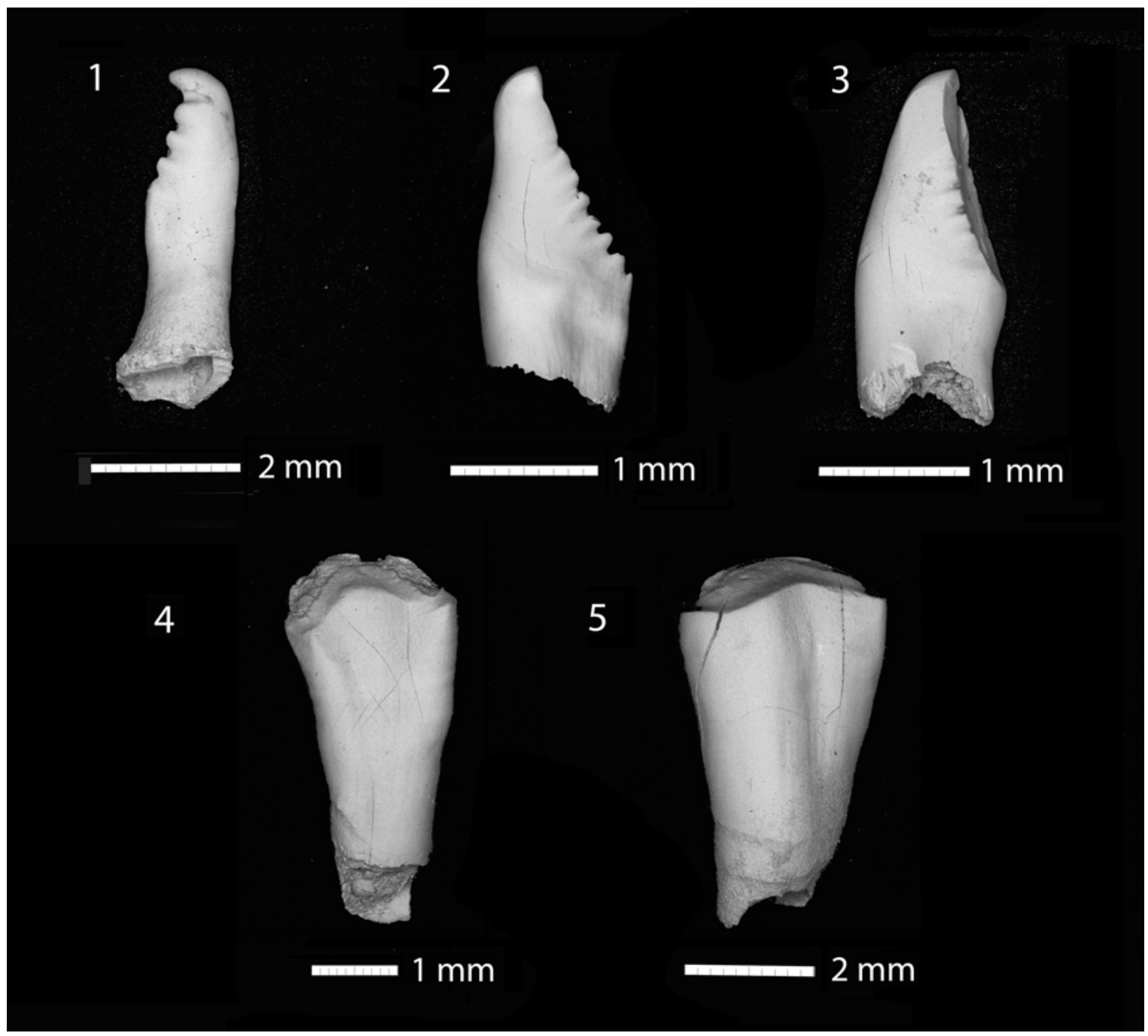

FIGURE 7. Fish remains from Haykadzor and Lusaghbyur localities, north-western Armenia. 1. Telestes cf. souffia, PIN 5595/201, pharyngeal tooth; 2-3. Pseudalburnus sp., PIN 5595/202, 203, pharyngeal teeth; 4-5. Capoeta sp., PIN 5595/204, 205, pharyngeal teeth.

\section{Genus PSEUDALBURNUS Sytchevskaya, 1989 Pseudalburnus sp.}

Figure 7.2-3

Material. Nine pharyngeal teeth, coll. PIN 5595. Locality. Lusaghbyur, bed 2, and Haykadzor, bed 4

Measurements. Pharyngeal teeth of main row range in height from 2.0 to $2.4 \mathrm{~mm}$.

Description. Teeth small, with tapered crowns slightly inflated towards the abdomen. The tooth stem is short. The hook is weakly expressed, barely projecting beyond the chewing surface level. The back of tooth is bent at the hook and above the neck, slightly deflected in the middle part. Chewing surface elongate, moderately narrowed, with slightly jagged external edge; the internal edge with gently wavy contour.

Comments. In general, the teeth are similar with those of Pseudalburnus Sytchevskaya from the Pliocene of Mongolia, differing from them mainly by narrower crown and chewing surface. Occurrence of Pseudalburnus sp. in the Middle Pleistocene of Armenia may suggest some faunal links between the Caucasian region and Central Asia at that time. A kind of indirect evidence in favour of such assumption can be derived from the wide latitudinal dispersal of the genus Alburnus in the Neogene. Its common occurrence in the PliocenePleistocene of Armenia (Bogachev, 1938; Vasilyan, $2008 b$ ) is paralleled by its finds in Pliocene of Sibe- 
ria (Sytchevskaya, 1989) and in the Miocene of Germany (Kinkelin, 1884).

Subfamily BARBINAE Bleeker, 1859

Genus CAPOETA Valenciennes, 1842

Capoeta sp.

Figure 7.4-5

Material. 17 pharyngeal teeth, coll. PIN 5595. Locality. Lusaghbyur, bed 2, and Haykadzor, bed 4

Measurements. Pharyngeal teeth of main row range in height from 16 to $19 \mathrm{~mm}$.

Description. Teeth of main row are large, long, chisel-shaped, flattened, with a crown markedly widened upwards and narrowed towards the tooth neck (Figure 7.4-5). The chewing surface is slightly sloped to the abdomen.

Comments. The teeth are similar to those of Capoeta sp. from the Pliocene Ericek locality in Turkey (van den Hoek Ostende et al., 2015, figure 4-c), as well as to the teeth of the modern Capoeta aculeata (Valenciennes, 1844) from Iran. In fresh waters of West Asia (Iraq, Syria, Iran, Turkey, Transcaucasia) the genus is represented by at least 10 species inhabiting the basins with rocky bottom, rich water vegetation and well-warmed bank zone (Ayvazyan et al., 2018).

Order ANURA Fischer, 1813

Family BUFONIDAE Gray, 1825

Genus BUFOTES Rafinesque, 1815

Bufotes viridis sensu lato (Laurenti, 1768)

Figure 8.1

Material. One fragmentary scapula, one coracoid, and two ilia, coll. GIN-1142.

Locality. Haykadzor, Armenia, early Middle Pleistocene.

Description and comments. The scapula is not complete, but longer than wide. The collum scapulae is relatively narrow and only slightly curved. The fossa supraglenoidalis is shallow as in $B$. viridis s. I. The coracoid is thick in the middle part and has a poorly expanded pars epicoracoidalis.

The ilia show the presence of two distinct bulges on the anterolateral side of the tuber superior and well-developed preacetabular fossa. These features are typical for $B$. viridis $s$. I. (Böhme, 1977). Bufotes viridis s. I. (or B. viridis species group) is widely distributed and includes several species. The green toads from Balkans, Anatolia, and Caucasus were assigned to $B$. variabilis (Pallas, 1769) (Stöck et al., 2006, 2008). There are no published accounts providing osteological characters to support its taxonomic identification. Therefore, here we use $B$. viridis s. I. in the traditional sense, encompassing $B$. variabilis and other species of the group. Bufotes viridis s. I. is present in the extant fauna of Armenia and is widespread throughout the region; it prefers open landscapes with moderately arid climatic conditions (Arakelyan et al., 2011).

\section{Family RANIDAE Rafinesque, 1814 Genus RANA Linnaeus, 1758 Rana sp.}

Figure 8.2-3

Material. One scapula, ten fragmentary ilia, coll. GIN-1142.

Locality. Haykadzor, Armenia, early Middle Pleistocene.

Description and comments. The scapula is relatively short and wide. The crista supraglenoidalis is long and well-pronounced. The ilia are represented mostly by the acetabular parts. The dorsal crest is relatively high. The tuber superior is poorly developed and bears one laterally projected tubercle. The characters of scapula and ilia listed above allow their attribution to the genus of brown frogs Rana (Böhme, 1977; Ratnikov, 2001). But due to fragmentary preservation the precise taxonomic identification of the material is impossible. Within the genus Rana, the only Rana macrocnemis Boulenger, 1885, is currently known in Armenia. It occurs in humid and dry places along ravines of small rivers and streams (Arakelyan et al., 2011; Kuzmin, 2012). Besides, the fragments of two ranid humeri are revealed in Haykadzor. They are relatively large and possibly belonging to the green frogs of the genus Pelophylax.

Order PERISSODACTYLA Owen, 1848

Genus EQUUS Linnaeus, 1758

Subgenus ALLOHIPPUS Kretzoi, 1938

Equus sp. ex gr. E. stenonis Cocchi, 1867

Figure 9

Material. Lower left premolar, p3 or p4, coll. GIN, unnumbered specimen.

Locality. Lusaghbyur, surface find near the Arapi deposits exposure, Armenia, ?early Middle Pleistocene.

Measurements. Occlusal length and width, $32.5 \mathrm{x}$ 20. Height of the tooth ca. $75 \mathrm{~mm}$.

Description. The molar is large and well-preserved, medium-worn. The double knot is of typical "stenonid" structure. Its composing elements, metaconid and metastylid, are almost symmetrical and have convex inner walls. Metaconid, especially the outer wall, is rounded and has a relatively broad opening $(2 \mathrm{~mm})$. Matastylid is more elliptic, has a narrow opening; its posteroexternal wall has 


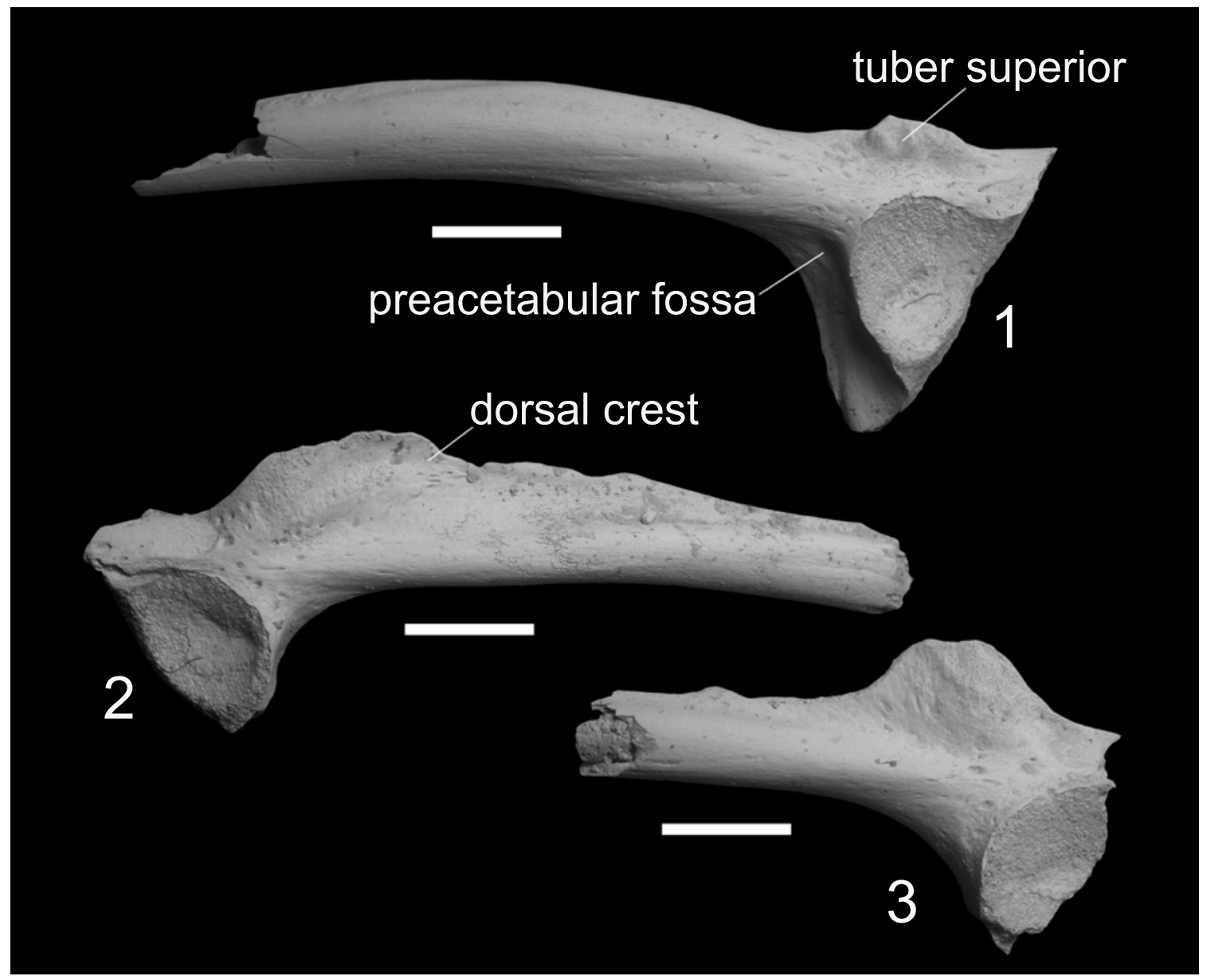

FIGURE 8. Amphibian remains from early Middle Pleistocene Haykadzor locality, Armenia. 1. Bufotes viridis s. I., GIN1142/120, left ilium of lateral view; 2. Rana sp., GIN-1142/121, right ilium of lateral view; 3. Rana sp., GIN-1142/122, left ilium of lateral view. Scale bars are $1 \mathrm{~mm}$.

a well-pronounced fold, posterointernal part is slightly pointed.

The linguaflexid has a distinct $\mathrm{V}$-shape, similarly to all representatives of $E$. stenonis s.l. Ectoflexid with a subtle "spur" is rather long. It approaches to the isthmus, not penetrating it (similarly to all premolars and slightly worn teeth). Entoconid with rounded inner wall and an anteroexternal beak-shaped bulge. The enamel is slightly thickened (1.0-1.2 mm), weakly plicated, with several (up to 3 ) smaller folds on the postflexid. The outer walls of protoconid and hypoconid are convex, similarly to stenonid horses of European subspecies. The latter, along with weakly plicated enamel of postflexid, is regarded as an archaic feature.

In addition to morphology of the double knot, it is the postflexid and postflexid index (IF index: postflexid length/tooth length) that are the most characteristic elements of lower cheek teeth. In our case, the length of the postflexid is $15.0 \mathrm{~mm}$ and $\mathrm{IF}=46.1$. This value exactly corresponds to the IF values in $\mathrm{P} 3$ and $\mathrm{P} 4$ of $E$. stenonis vireti Prat from Saint-Vallier (Eisenmann, 1981) and is relatively close to IF in P4 of E. stenonis bactrianus Zhegallo (47.0) from Tajikistan (Zhegallo, 1988). It is important that IF of the form under study substantially differs from IF in P3 and P4 of E. suessenbornensis Wüst $(\mathrm{IF}=48.0)$, the large archaic horse of late Early Pleistocene and early Late Pleistocene. This form was widespread from the southern Western Europe (Musil, 1969) to Eastern Europe and western Asia, including Transcaucasia (Akhalkhalaki, Georgia) (Vekua, 1962, 1986; Gabunia, Vekua, 1989; Alexeeva, 1977, and others), to Western Siberia (Foronova, 1990, 1998, 2001), Kazakhstan (Kozhamkulova, 1967), and probably Eastern Siberia (Sher, 1971; Forsten, 1986, and others). 


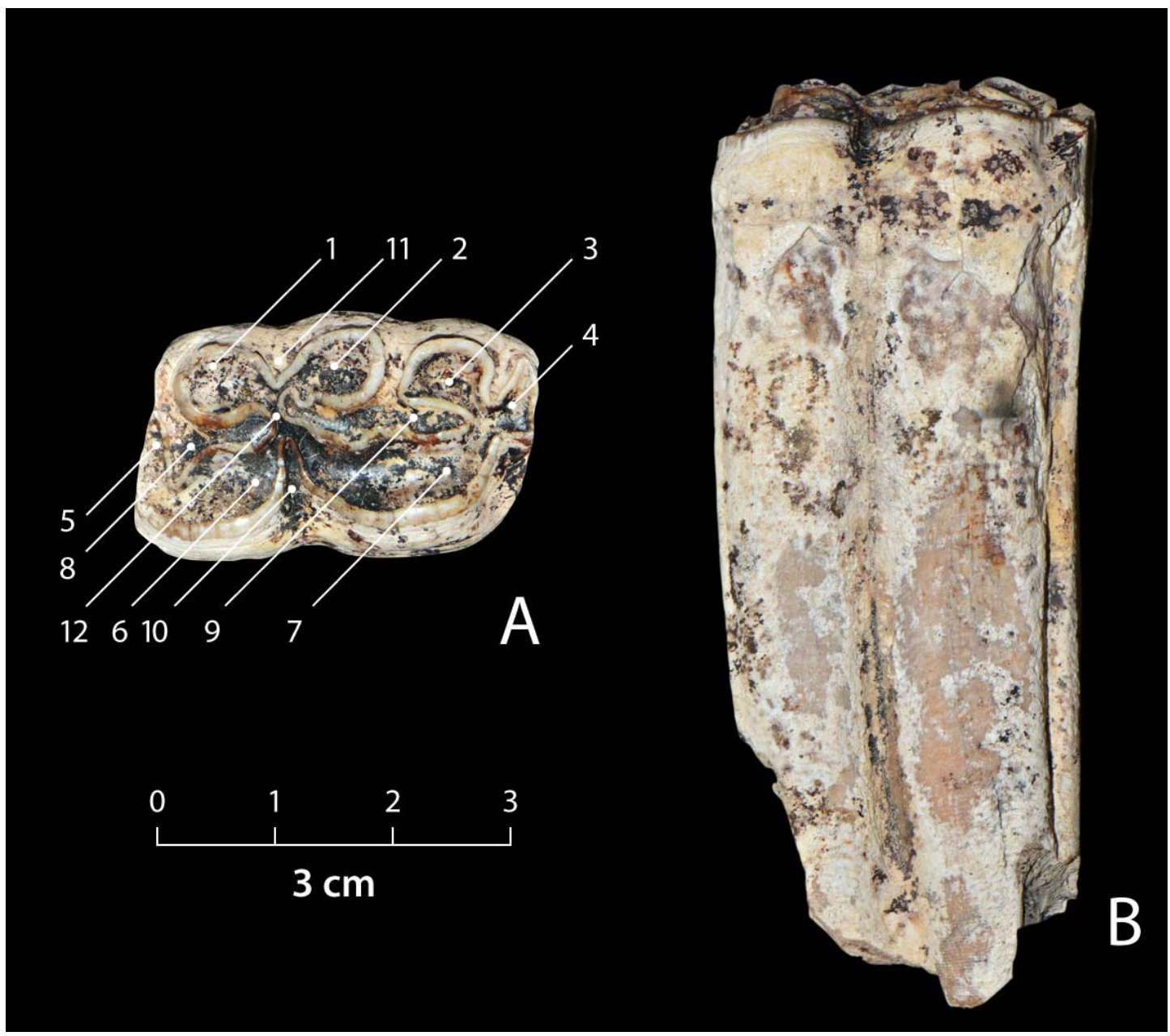

FIGURE 9. Equus sp. ex gr. E. stenonis, GIN, unnumbered specimen, Lower left p3? or p4, Lusaghbyur, Arapi Fm, Shirak Depression, early Middle Pleistocene, Armenia. A. Occlusal view with indicated elements of the tooth. 1. metaconid; 2. metastylid; 3. entoconid; 4. talonid; 5. paraconid; 6. protoconid; 7. hypoconid; 8. fossa anterior; 9. fossa posterior (postflexid); 10. ectoflexid; 11. linguaflexid; 12. isthmus. B. Buccal view.

Moreover, the horse from Shirak Depression markedly differs from $E$. suessenbornensis in composition of the double knot, especially its metastylid (it is always sub-triangular) and other dental elements. Peculiar angular outlines of all dental elements of $E$. suessenbornensis are determined by extremely high folding of the enamel, especially on lower cheek teeth.

Finally, this form has the most significant differences from caballoid horses, the group Equus (Equus) mosbachensis Reichenau, widespread in Eurasia at the very end of Early and in Middle Pleistocene. Unlike stenonid forms, caballoid horses show typically caballine, sharply asymmetric double knot with wide and low-sloping recess. Its metaconid is of oval or irregular shape and has a long stem; metastylid is elongated and has an extended and sharpened posterointernal part.

Thus, the morphology of the studied tooth considerably differs from that of Suessenborn and Mosbach horses and fits that of the E. stenonis group. It is possible that it represents one of the late forms of stenonid horses studied by many researchers (Gromova, 1949; Musil, 1969; De Giuli, 1972, 1986; Azzaroli, 1987, and others). The West European sequence of species includes $E$. stenonis vireti $-E$. stenonis stenonis - E. stenonis senezensis Prat; the Asian record documents $E$. stenonis bactrianus Zhegallo. The described horse of Armenia can be reliably determined as Equus (Allohippus) sp. (ex gr. E. stenonis). It dates to early Middle Pleistocene and most likely inhabited open steppe-like landscapes. 
Comments. Fossil horses are known from several localities in Transcaucasus. The Late Villafranchian fauna of Dmanisi documents a larger and smaller stenonid horses (Azzaroli, 1983; Forsten, 1999; Gabunia, Vekua, 1989, and others), the latest Villafranchian fauna of Akhalkalaki includes $E$. suessenbornensis Wüst (Vekua, 1962, 1986; Alexeeva, 1977, and others). There is no common opinion on the origin of $E$. suessenbornensis with alternatives ranging from a direct descent from $E$. stenonis (Gromova, 1949; Azzaroli, 1982, 1987) to the migrational hypothesis based on a lack of affinities of $E$. suessenbornensis with any early European horses and a substantial dissimilarities from $E$. stenonis in a number of characters (Musil, 1969). In Armenia, the horse of the Gyumri complex has been assigned to $E$. stenonis (Avakyan, 1957, 1959). Sayadyan (1972) refers to the personal communication of L.I. Alexeeva that "the horse in question is younger than stenonis typical for the Khapry faunal complex."

\section{Order EULYPOTYPHLA Waddell, Okada, Hasegawa, 1999 \\ Family SORICIDAE Fischer, 1814 \\ Genus NEOMYS Kaup, 1829}

Neomys cf. hintoni Zaitsev and Baryshnikov, 2002

Figure 10.1

Material. 1 fragmentary left mandible, GIN-1142/2. Locality. Haykadzor, Armenia, early Middle Pleistocene.

Measurements. Height of ascending ramus $=3.6$; articular process height $=1.85$; upper facet width $=$ 0.6 ; lower facet width $=1.17$; basal width of internal temporal fossa $=1.0$.

Comments. Small size, the single mandibular foramen, and especially a fossa on the buccal side of the ascending ramus anterior to the condyle fit the morphology of $N$. hintoni from the mid Middle Pleistocene level of the lowermost bed 7 of the Treugolnaya Cave in the North Caucasus (Zaitsev and Baryshnikov, 2002). The described form is also similar in size and morphology to N. newtoni Hinton from early Middle Pleistocene of upper freshwater bed of West Runton (Hinton, 1911; Maul and Parfitt, 2010). The variability of buccal fossa in $N$. hintoni, the character differentiating it from $N$. newtoni, is not known. A slight concavity on the buccal side of the ascending ramus is illustrated for one specimen of topotypic N. newtoni (Maul and Parfitt, 2010: figure 2, H). The Armenian smaller Neomys is among the oldest records of this group in Europe and western Asia. It clearly differs from Recent $N$. anomalus in slightly smaller size, single mandib- ular foramen, and the presence of the buccal fossa.

\author{
Genus SOREX Linnaeus, 1758 \\ Sorex cf. runtonensis Hinton, 1911
}

Figure 10.2

Material. Fragmentary right mandible with $\mathrm{m} 1-\mathrm{m} 2$ and ascending ramus, GIN-1142/3; fragment of mandible with $\mathrm{m} 2$, GIN-1142/4.

Locality. Haykadzor, Armenia, early Middle Pleistocene.

Measurements. Height of ascending ramus $>3.0$; articular process height $=1.7$; upper facet width $=$ 0.72 ; lower facet width $=1.1$; mandibular length from the base of ascending ramus to mental foramen $=4.65$; length $\mathrm{m} 1-\mathrm{m} 3=$ ca. 3.5 ; length $\mathrm{m} 1=$ 1.5 ; length $\mathrm{m} 2=1.25,1.2$; mandibular height below $\mathrm{m} 2=1.25,1.20$.

Comments. The medium size soricid, and in structure of condyle generally matches $S$. runtonensis from Middle Pleistocene of Europe and Caucasus (Hinton, 1911; Rzhebik-Kowalska, 1991; Zaitsev and Baryshnikov, 2002; Maul and Parfitt, 2010).

Order RODENTIA Bowdich, 1821

Family CRICETIDAE Fischer, 1817

Subfamily ARVICOLINAE Gray, 1821

Genus MIMOMYS F.Major, 1902

Subgenus MICROTOMYS Méhely, 1914

Mimomys intermedius (Newton, 1881)

Figures 11-13, Tables 3-8

non 1845a Arvicola intermedia Bonaparte, p. 350: nomen nudum

non 1845b Arvicola intermedia Bonaparte, p. 30: nomen nudum

$1881 \quad$ Arvicola (Evotomys) intermedia Newton, p. 258.

1882 Arvicola intermedia Newton, partim, p. 83, pl. XIII, figs. 1-3, 12.

1902 Mimomys intermedius (Newton); F.Major, p. 104-107, figs. 1, 11-13, 21-26.

$1910 \quad$ Mimomys savini Hinton, p. 491.

$1910 \quad$ Mimomys majori Hinton, p. 491.

1914 Microtomys intermedius (Newton); Méhely, p. 211-214, taf. VI, figs. 8, 9.

$1958 \quad$ Mimomys milleri Kretzoi, p. 55.

1965 Mimomys intermedius (Newton); Topachevsky, p. 112-118, figs. 28, 29.

Material. $12 \mathrm{~m} 1,12 \mathrm{~m} 2,11 \mathrm{~m} 3,16 \mathrm{M} 1,18 \mathrm{M} 2,9$ M3, GIN-1141/5-80.

Locality. Haykadzor, Armenia, early Middle Pleistocene

Measurements. See Tables 3-8.

Description. The large size water vole with rhizodonty strongly shifted to early stages of root forma- 


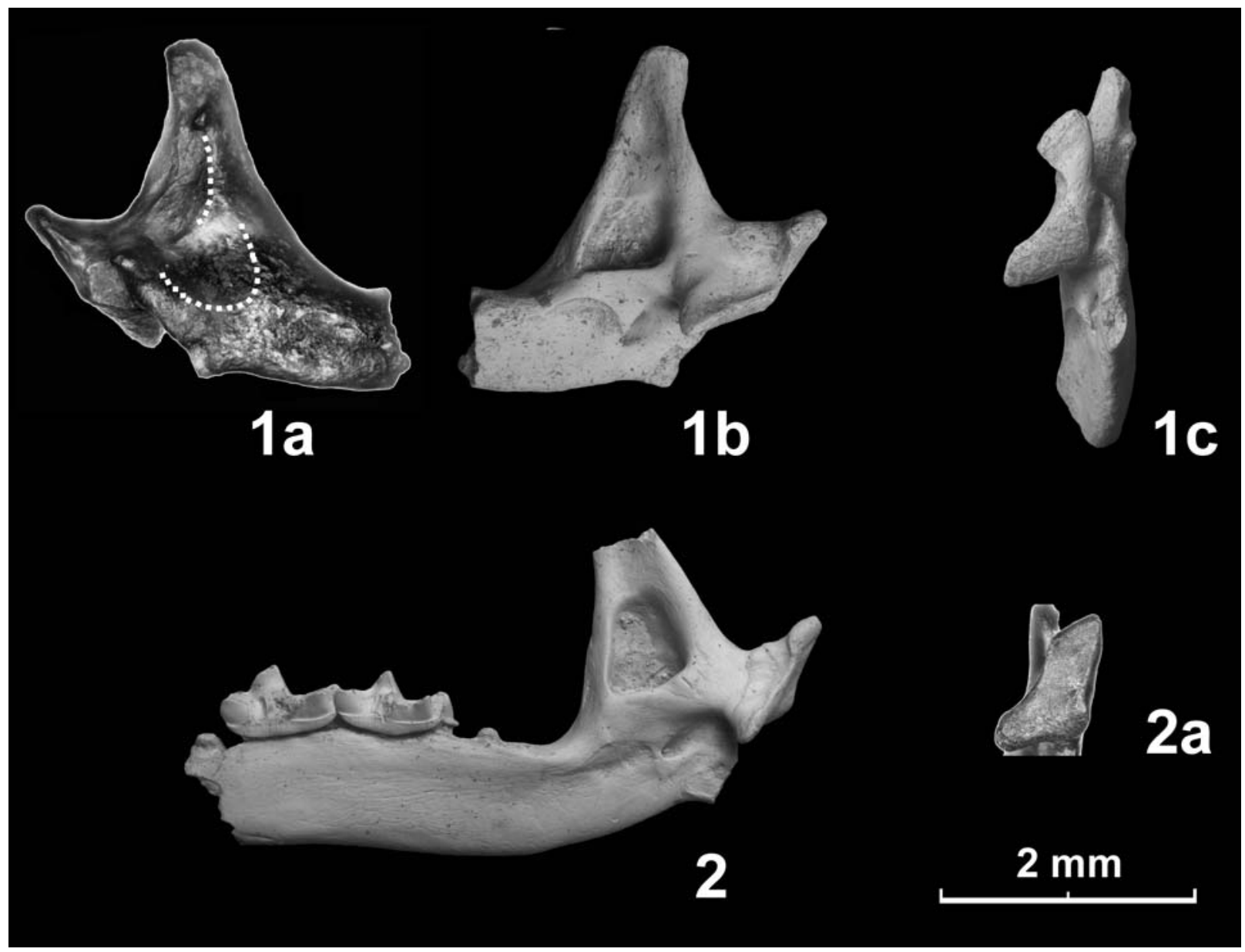

FIGURE 10. Soricidae from early Middle Pleistocene, Haykadzor, Armenia. 1. Neomys cf. hintoni, GIN-1142/2, ascending branch of fragmentary right mandible, $1 \mathrm{a}$. lingual view with buccal fossa indicated by dashed line, $1 \mathrm{~b}$. labial view, 1c. condyle view; reversed. 2. Sorex cf. runtonensis, GIN-1142/3, right mandible, lingual view, 2a. condyle view.

tion, well expressed pleurorhiz position of roots in $\mathrm{m} 2$, two-rooted upper molars, with the protocone root of M1 broadly fused with the anterior root, very high but still measurable dentine tracts, mimomyine features (islet, Mimomys-ridge) expressed in youngest specimens of $\mathrm{m} 1$. The sample shows a predominance of younger, higher crowned specimens as shown in the violin diagram (Figure 13).

m1. The ontogenetically younger specimens shows the crown heights around $5 \mathrm{~mm}$. Several youngest molars $(n=3$, Figure 11) show enamel islets, oval to circular in shape. Mimomys ridge is weakly expressed in the upper parts of crowns in several youngest specimens $(n=3$, Figure 11). Enamel differentiation changes from nearly undifferentiated condition at juvenile rootless stage to strongly negatively (=Mimomys type with thicker trailing edges) differentiated in more worn specimens with well developed roots.
M3. Third upper molars show typical structure (Figure 12) with deep, posterolingual reentrant angle (LRA3) filled with cement and without signs of insulation. The posterior lobe is rounded at early stages and grades to more triangular shaped with wear.

Comparison. The small sample of $M$. intermedius from Haykadzor is generally close in size and morphology to other known Cromerian populations described from Europe (Agadjanian and Kondrashov, 2007; Maul and Parfitt, 2010). The somewhat smaller mean values of occlusal length in $\mathrm{m} 1$ and M3 may account for the earliest Cromerian age of the Armenian sample, and, alternatively, may be related to the higher share of occlusally smaller molars at younger age stages in this sample (Figure 13). The size of $\mathrm{m} 1$ in Mimomys from Armenia is notably smaller than described for successive late Early Pleistocene samples of archaic water voles in Spain (Lozano-Fernández et al., 2013a, b). 

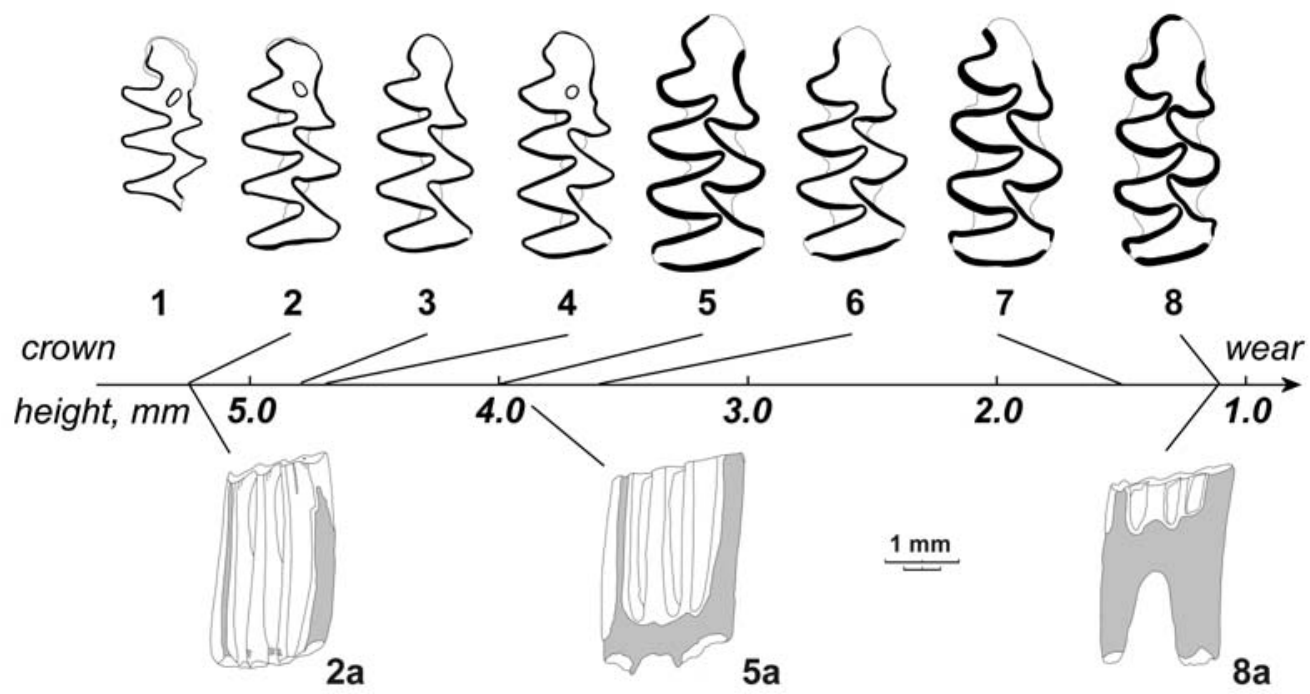

FIGURE 11. Dental morphology of the fossil water vole Mimomys intermedius, early Middle Pleistocene, Haykadzor, Armenia. 1-8. GIN-1142/5-12, first lower molar, m1, occlusal view; a, labial view. All molars are shown as right side, numbers 1, 5 are reversed. Horizontal axis illustrates decreasing crown heights in the course of wear (higher crowned, younger specimens are to the right, more worn, to the left). Occlusal and lateral scales, $1 \mathrm{~mm}$.

This clearly shows that regional size differences in ancient water voles probably override the general evolutionary trend to size increase in this species and cannot be used for accurate long distance correlations. More reliable for comparisons between separate fossil samples are likely size independent evolving characters like hypsodonty (e.g., crown height/length ratio, Agadjanian and Kondrashov, 2007), and especially the enamel differentiation index. Indeed, the mean SDQ value of the studied

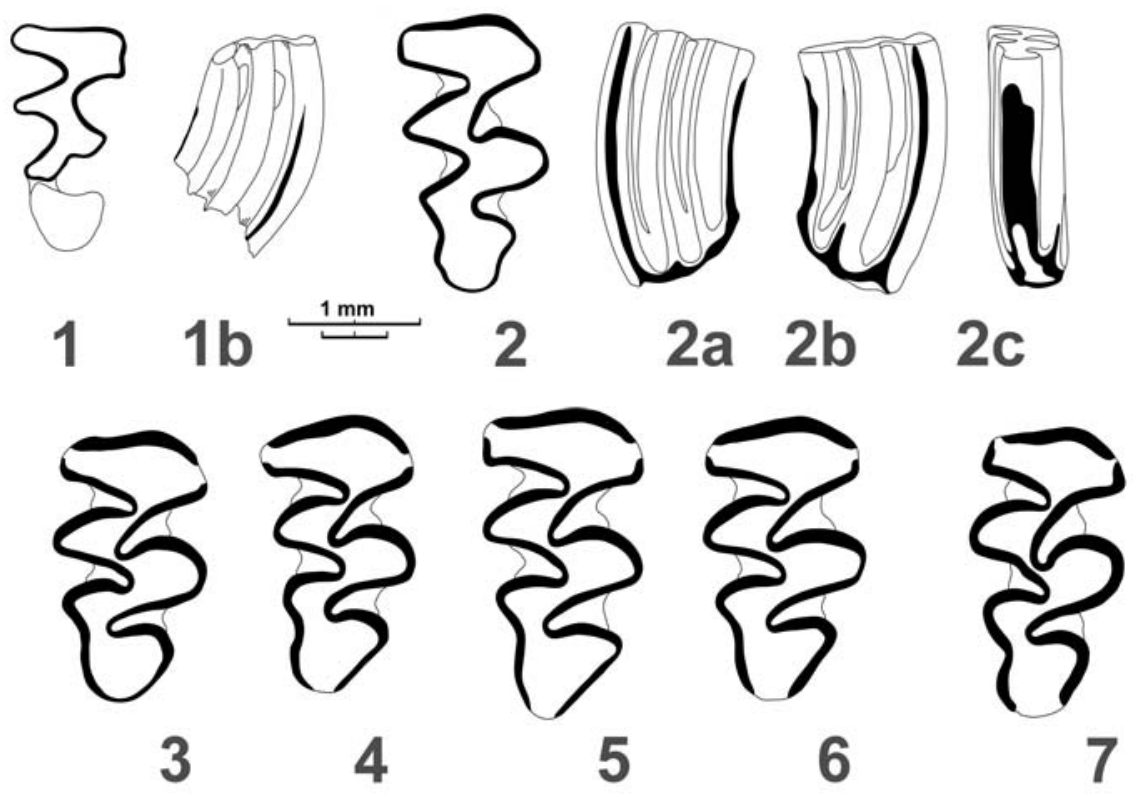

FIGURE 12. Dental morphology of the fossil water vole Mimomys intermedius, early Middle Pleistocene, Haykadzor, Armenia. 1-7. GIN-1142/68-75, third upper molar, M3, occlusal view; a, labial view; b, lingual view; c, posterior view. All molars are shown as right side, numbers 4, 6, 7 are reversed. Occlusal and lateral scales, $1 \mathrm{~mm}$. 


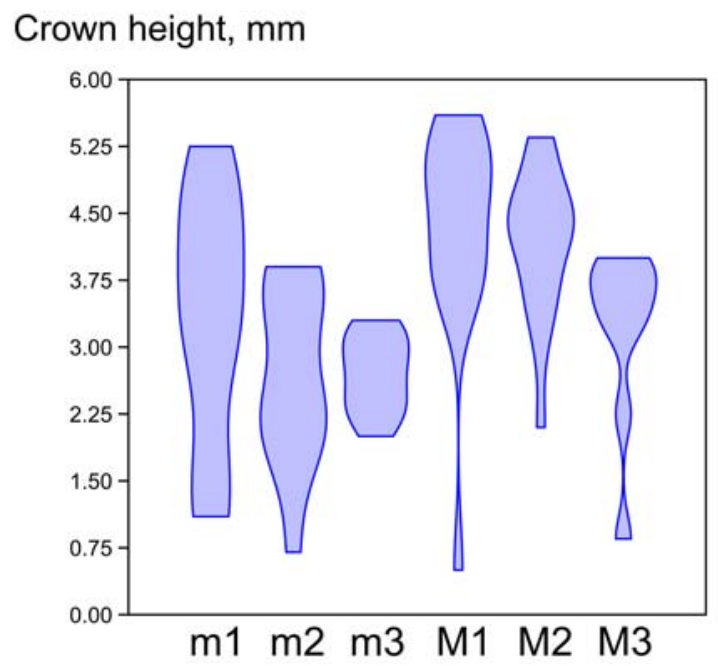

FIGURE 13. Mimomys intermedius, early Middle Pleistocene, Haykadzor, Armenia. Violin diagram showing distribution of frequencies of crown heights in molar types.

sample generally fits the range $130-140$ observed in middle European Mimomys intermedius from early Middle Pleistocene (Maul et al., 2000; Maul and Parfitt, 2010). Notably higher (e.g., more archaic) SDQ values, ranging between 140 and160, are known for Early Pleistocene populations in south-western (Fernández et al., 2013b) and northern (Maul et al., 2000) Europe.

Taxonomic comment. The name Mimomys intermedius (Newton, 1881) has a priority over Mimomys savini Hinton, 1910, due to the name Arvicola intermedia Bonaparte, 1845, that was regarded a senior synonym of $A$. intermedia Newton, 1881 (e.g., Kretzoi, 1958), that was never validly described. It was first stated by Miller (1912: p. 672) and later by Ellerman and Morrison-Scott (1966: p. 703). Based on this information, Topachevsky (1965) clearly stated the validity of $M$. intermedius (Newton, 1881) for fossil water voles with rhizodont molars. We checked relevant publications of Bonaparte (Bonaparte, 1845a, b). Both of these, published in Milan in the proceedings of the Italian scientific congress and as a separate edition, are reiterations of the same taxonomic inventory of European mammals. Indeed, none of these papers contains anything but listing $A$. intermedia, without giving any characters, as a questionable synonym to Arvicola bailloni (now regarded as a younger synonym of Microtus agrestis) with the reference to the usage of Sélys-Longchamps. None of the arvicolid papers of SélysLongchamps of that period contain any references to "Arvicola intermedia", including the checklist of European voles immediately preceding in the book the vole list of $1845 \mathrm{~b}$ by Bonaparte (Sélys-Longchamps, 1845). We, therefore, regard " $A$. intermedia Bonaparte, 1845" a nomen nudum. The origin of the name "intermedia", regarding the British fossil water voles, ascends to the work of Owen (1846) who noted that the form coming from "older pliocene crag near Norwich" is intermediate in size between the recent "Water vole (Arvicola amphibia,) and the Field-vole (Arvicola arvalis)". Newton (1881) when coining a new name for this vole referred to "the intermediate position which it

TABLE 3. Measurements and indices, m1, Mimomys intermedius, Haykadzor.

\begin{tabular}{lccccccc}
\hline & $\mathbf{n}$ & Mean & SE & Min & Max & SD & CV \\
\hline W & 10 & 3.17 & 0.0667 & 2.85 & 3.45 & 0.2109 & 6.65 \\
A & 12 & 1.44 & 0.0377 & 1.15 & 1.6 & 0.1309 & 9.09 \\
Height & 12 & 1.285 & 0.0220 & 1.2 & 1.45 & 0.0762 & 5.93 \\
Asd & 12 & 3.35 & 0.4084 & 1.1 & 5.25 & 1.4149 & 42.28 \\
Hsd & 5 & $>4.58$ & - & $>4$ & 4.58 & - & - \\
Hsld & 5 & $>4.57$ & - & $>4$ & 4.85 & - & - \\
$H H-$ & 5 & $>4.75$ & - & $>4.4$ & 5 & - & - \\
index & 5 & $>4.32$ & - & $>4.1$ & 4.4 & - & - \\
Hsd/L & 5 & $>1.47$ & - & $>1.2$ & 1.7 & - & - \\
Lbas & 10 & 3.33 & 0.0442 & 3.15 & 3.6 & 0.1398 & 4.19 \\
A/L & 10 & 40.6 & 0.7770 & 37.3 & 44.3 & 2.4571 & 6.04 \\
SDQ & 10 & 133.89 & 3.8511 & 118.63 & 157.79 & 12.1781 & 9.09 \\
BTQ & 11 & 131.84 & 5.0729 & 105.10 & 162.11 & 16.8250 & 12.76 \\
\hline
\end{tabular}


TABLE 4. Measurements and indices, m2, Mimomys intermedius, Haykadzor.

\begin{tabular}{lccccccc}
\hline & $\mathbf{n}$ & Mean & SE & Min & Max & SD & CV \\
\hline L & 10 & 1.99 & 0.0380 & 1.8 & 2.2 & 0.1202 & 6.03 \\
W & 12 & 1.31 & 0.0371 & 1 & 1.45 & 0.1286 & 9.81 \\
Height & 12 & 2.69 & 0.2879 & 0.7 & 3.9 & 0.9974 & 37.06 \\
Asd & 4 & $>4.19$ & - & $>4$ & $>4.4$ & - & - \\
Hsd & 4 & $>3.64$ & - & $>3.4$ & $>3.9$ & - & - \\
Hsld & 4 & $>3.77$ & - & $>3.6$ & $>4.1$ & - & - \\
HH-index & 4 & $>3.85$ & - & $>3.77$ & $>3.94$ & - & - \\
Hsd/L & 3 & $>1.86$ & - & $>1.74$ & $>1.95$ & - & - \\
Lbas & 8 & 2.17 & 0.0422 & 1.95 & 2.3 & 0.1193 & 5.5 \\
\hline
\end{tabular}

TABLE 5. Measurements and indices, m3, Mimomys intermedius, Haykadzor.

\begin{tabular}{lccccccc}
\hline & $\mathbf{n}$ & Mean & SE & Min & Max & SD & CV \\
\hline L & 7 & 1.82 & 0.0359 & 1.65 & 1.9 & 0.0951 & 5.22 \\
W & 11 & 1.04 & 0.0208 & 0.9 & 1.11 & 0.0690 & 6.65 \\
Height & 11 & 2.69 & 0.1302 & 2 & 3.3 & 0.4321 & 16.03 \\
Asd & 3 & $>3.6$ & - & $>3.5$ & $>3.7$ & - & - \\
Hsd & 3 & $>2.77$ & - & 2.5 & $>3.2$ & - & - \\
Hsld & 3 & $>2.7$ & - & 2.7 & $>2.7$ & - & - \\
HH-index & 2 & $>3.34$ & - & $>3.25$ & $>3.43$ & - & - \\
Hsd/L & 2 & $>3.87$ & - & $>3.79$ & $>3.93$ & - & - \\
Lbas & 7 & 1.84 & 0.1059 & 1.73 & 1.95 & 0.1498 & 8.12 \\
\hline
\end{tabular}

TABLE 6. Measurements and indices, M1, Mimomys intermedius, Haykadzor.

\begin{tabular}{lccccccc}
\hline & $\mathbf{n}$ & Mean & SE & Min & Max & SD & CV \\
\hline L & 12 & 2.69 & 0.0369 & 2.5 & 2.91 & 0.1274 & 4.73 \\
W & 16 & 1.65 & 0.0250 & 1.5 & 1.8 & 0.1001 & 6.07 \\
Height & 16 & 4.33 & 0.3090 & 0.5 & 5.6 & 1.2360 & 28.51 \\
As & 4 & $>5.09$ & - & 4.85 & $>5.6$ & - & - \\
Asl & 4 & $>5.6$ & - & $>5.5$ & $>5.8$ & - & - \\
Prs & 4 & $>5.6$ & - & 4.45 & $>4.75$ & - & - \\
Ds & 4 & $>5.5$ & - & $>5.5$ & $>5.87$ & - & - \\
PA-index & 4 & $>4.62$ & - & $>4.55$ & $>4.77$ & - & - \\
As/L & 3 & $>1.89$ & - & $>1.82$ & $>1.96$ & - & - \\
Lbas & 12 & 2.67 & 0.0361 & 2.55 & 3 & 0.1249 & 4.68 \\
\hline
\end{tabular}

occupies between the Arvicola amphibia and Arvicola (Evotomys) glareola."

The name Mimomys savini Hinton, 1910, widely, but not overwhelmingly (see Méhely, 1914, Topachevsky, 1965, and others) used in the European literature, is a younger synonym of M. intermedius (Newton, 1881). Méhely (1914) attributed $M$. intermedius to his new genus Microtomys where he placed rhizodont mimomyine voles with the lateral position of the posterior root in $\mathrm{m} 2$ relative to the incisor (pleurorhiz condition). Topachevsky (1965, p.111) considered Microtomys as a subgenus of Mimomys, and in the sense of the International Code of Zoological Nomenclature established its type species by subsequent designation (ICZN, 1999: 69.1) fixing Arvicola (Evotomys) intermedius Newton, 1881, as the type species of the genus Microtomys Méhely, 1914.

\section{Genus Terricola Fatio, 1867}

Terricola sp.

Figure 14

Material. $1 \mathrm{~m} 1,2 \mathrm{~m} 1$ fragments, $1 \mathrm{M} 1,1 \mathrm{M} 2$, GIN$1141 / 2-7$ 
TABLE 7. Measurements and indices, M2, Mimomys intermedius, Haykadzor.

\begin{tabular}{lccccccc}
\hline & $\mathbf{n}$ & Mean & SE & Min & Max & SD & CV \\
\hline L & 14 & 2.17 & 0.0256 & 1.92 & 2.3 & 0.0959 & 4.43 \\
W & 18 & 1.36 & 0.03 & 1.05 & 1.52 & 0.1095 & 8.05 \\
Height & 18 & 4.17 & 0.1924 & 2.1 & 5.35 & 0.82 & 19.55 \\
As & 3 & $>5.08$ & - & 4.7 & $>5.35$ & - & 0 \\
Prs & 3 & $>4.53$ & - & 4.3 & $>4.8$ & - & 0 \\
Ds & 4 & $>4.5$ & - & $>4.2$ & $>4.8$ & - & 0 \\
PA-index & 2 & $>4.37$ & - & $>4.2$ & $>4.51$ & - & 0 \\
As/L & 3 & $>2.33$ & - & $>2.14$ & $>2.48$ & - & 0 \\
Lbas & 14 & 2.14 & 0.0261 & 1.95 & 2.3 & 0.0978 & 4.56 \\
\hline
\end{tabular}

TABLE 8. Measurements and indices, M3, Mimomys intermedius, Haykadzor.

\begin{tabular}{llcccccc}
\hline & $\mathbf{n}$ & Mean & SE & Min & Max & SD & CV \\
\hline L & 9 & 2.18 & 0.0587 & 1.7 & 2.3 & 8.3097 & 8.31 \\
W & 9 & 1.14 & 0.0319 & 0.9 & 1.23 & 8.4365 & 8.44 \\
P & 9 & 0.93 & 0.025 & 0.8 & 1.05 & 0.075 & 8.04 \\
Height & 9 & 3.18 & 0.3405 & 0.85 & 4 & 32.1409 & 32.14 \\
Prs & 4 & 3.65 & 0.1190 & 3.4 & 3.9 & 6.5218 & 6.52 \\
As & 4 & 3.85 & 0.0736 & 3.7 & 4 & 3.8232 & 3.82 \\
Ds & 4 & 2.56 & 0.1434 & 2.15 & 2.8 & 11.1947 & 11.19 \\
PA-index & 4 & 3.87 & 0.0492 & 3.77 & 3.96 & 2.5418 & 2.54 \\
As/L & 4 & 1.82 & 0.0364 & 1.76 & 1.93 & 0.0729 & 3.99 \\
P/L & 9 & 44.14 & 0.7034 & 40.91 & 47.73 & 2.1102 & 4.78 \\
Lbas & 9 & 2.08 & 0.0430 & 1.9 & 2.3 & 0.1291 & 6.21 \\
\hline
\end{tabular}

Locality. Krasar, Armenia, early Middle Pleistocene.

Description. The microtine vole from this site shows well-developed positive (Microtus type) enamel differentiation $(B T Q=43,9, S D Q=60$, $\mathrm{n}=1$ ), broadly fused triangles T4-T5 forming the "Pitymys-rhombus", and initial complication of posterior side (T4) of upper molars. The well-preserved first lower molar $(L=2.47 ; W=0.94 ; A=1.27$; $\mathrm{A} / \mathrm{L}=51.4)$ and two fragmentary $\mathrm{m} 1(\mathrm{~W}, \mathrm{~A}: 0.9 \mathrm{x}$ $1.5 ; 0.94 \times 1.27$ ) show characteristic confluent T4T5 with somewhat incurving tip of third reentrant (LRA3). In one specimen (Figure 14.3), T6-T7 show an incomplete alternation. Upper molars (M1 and M2, L, W: $2.01 \times 1.16$; $1.56 \times 0.98$ ) demonstrate initial complication at the posterior side (Figure 14.4-5).

Comparison. The vole from Krasar shows shorter $(\mathrm{A} / \mathrm{L}=51, \mathrm{n}=1)$ and more compact anteroconid cap with more shallow reentrants BRA4 and LRA5 than any extant Terricola of the Caucasus and Asia Minor (Kryštufek and Vohralík, 2005). The relative anteroconid length $(A / L)$ in recent subterranean voles of the region well exceeds 51 in most individ- uals. The Armenian vole is also less advanced in complication degree of the anteroconid than Late Pleistocene T. majori from Kudaro Cave (Baryshnikov and Baranova, 1983).

Comments. Terricola from early Middle Pleistocene deposits of Shirak Fm were described by Agadjanan and Melik-Adamyan (1985) and MelikAdamyan (1994). Noting short and poorly dissected anteroconid cap in this vole these authors assigned it to most morphologically primitive of the extant subterranean voles, Pitymys duodecimcostatus. Having in mind the geological antiquity and geographic remoteness of Armenia from the Mediterranean region, this assignment is obviously very approximate. The single M3 so far described for the Armenian vole (Melik-Adamyan, 1994) fits modern Terricola morphology in confluent T2 and T3, and in "principalis" morphotype with two lingual salient angles (LSA4 and LSA5) on the posterior lobe. We would rather favour a detection of a very primitive stage of the Caucasus Terricola. The basal position of the modern T. majori in the molecular tree of Terricola (Martínková et al., 2007; Tougard, 2017) suggests an early presence of the 

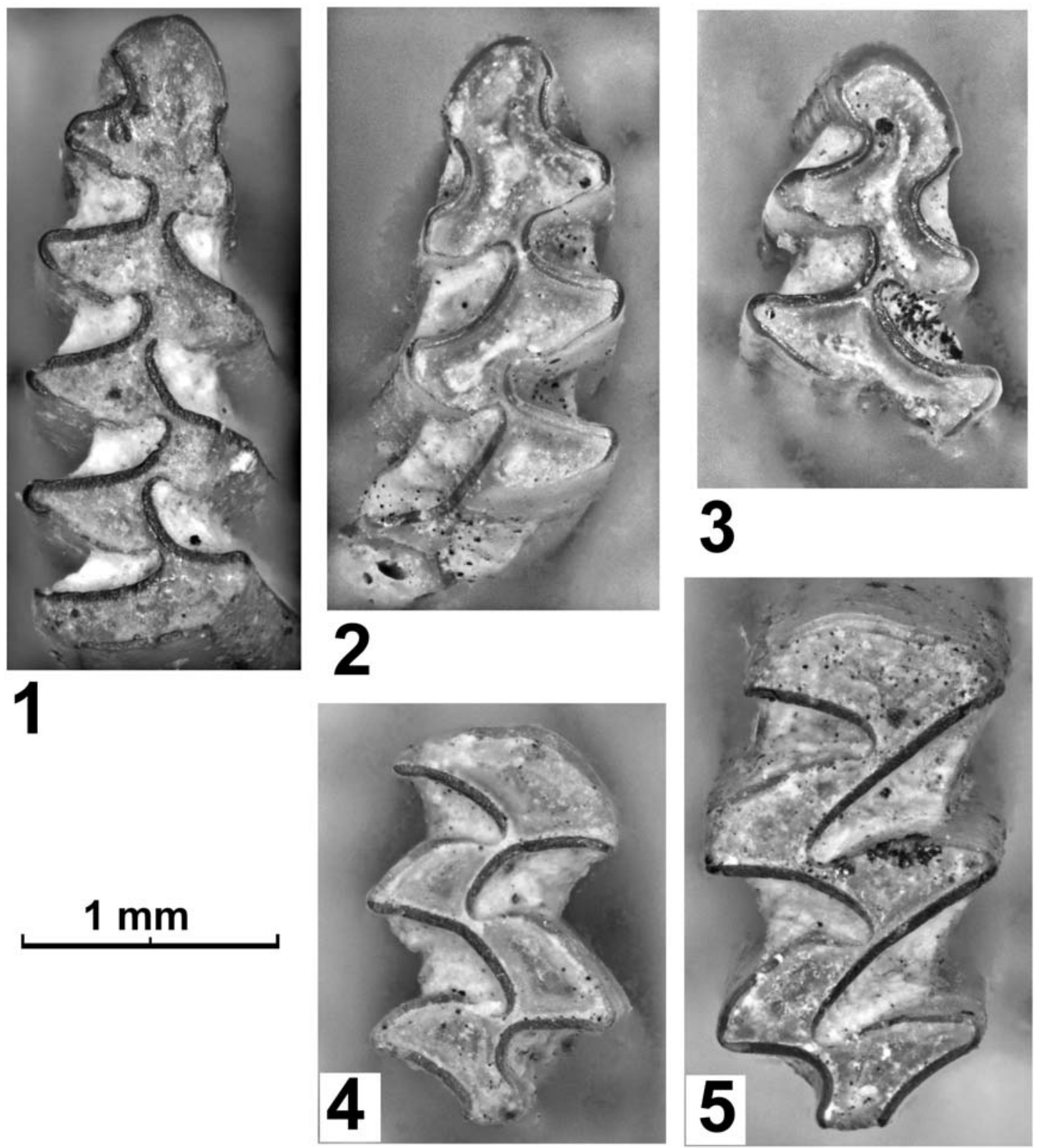

FIGURE 14. Dental morphology of the fossil vole Terricola sp., early Middle Pleistocene, Krasar, Armenia. 1-3. GIN1141/2-4, first lower molar, m1; 4. GIN-1141/5, second upper molar, M2; 5. GIN-1141/6, first upper molar, M1. Occlusal view. All molars are shown as left side, numbers 1, 3, 4 are reversed. Scale equals $1 \mathrm{~mm}$.

group in the Caucasus. The morphological archaism of the described forms, however, hampers a reliable attribution to any of the extant species, e.g., T. majori and T. daghestanicus, and implies an existence of a new chronospecies to be described in future when more complete material will be available. The state of evolution of the vole from Krasar (upper Akhuryan basin) is very close to that hitherto described from early Middle Pleistocene sites of Shirak Fm. We, therefore, infer a sim- ilar age for the fauna of Krasar (Trifonov et al., 2016). Our initial interpretation of one incomplete specimen (Figure 14.3) as belonging to ?Chionomys, based on a slightly larger size and more dissected anteroconid cap, is questionable. Many of its characters are indeed close to other Terricola specimens from Krasar but more material is needed for a reliable taxonomic placement.

Microtus ex gr. nutiensis Chaline, 1972

Figure 15, Table 9 

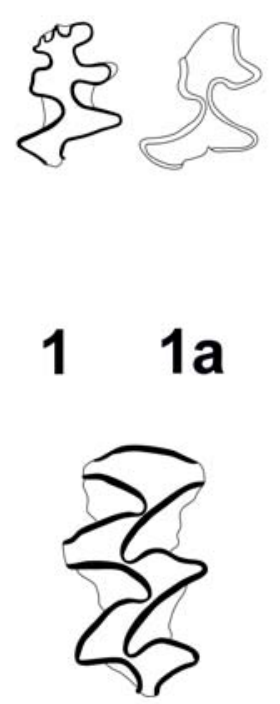

7
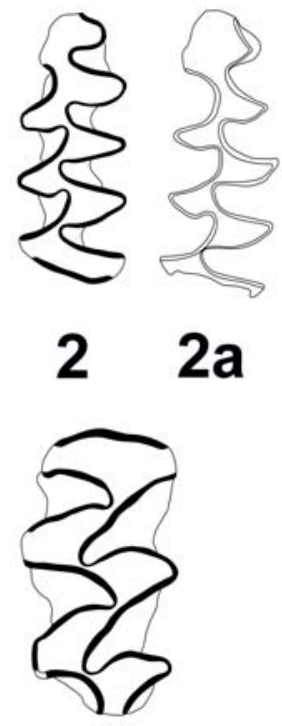

8

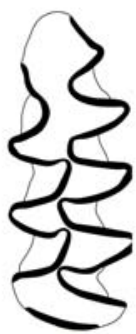

3

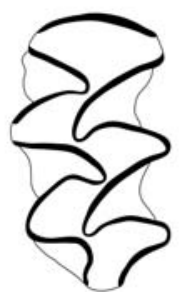

9
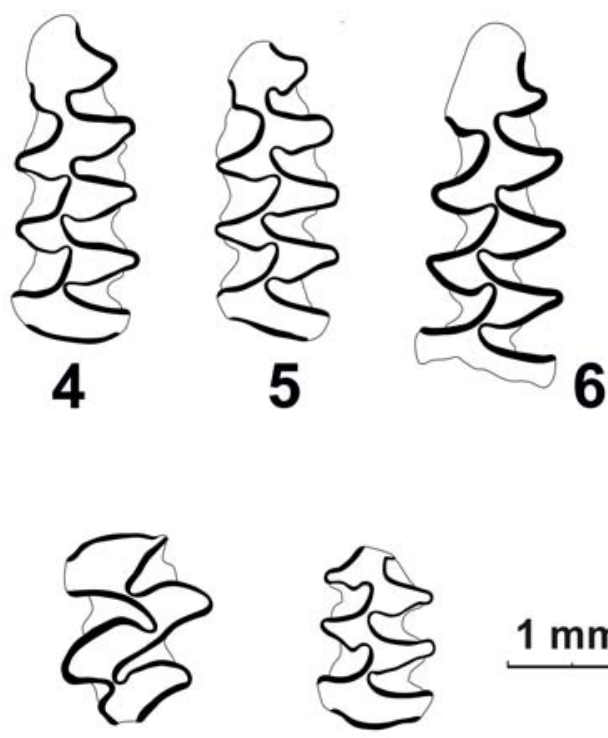

$1 \mathrm{~mm}$

FIGURE 15. Dental morphology of the fossil vole Microtus ex gr. nutiensis, early Middle Pleistocene, Haykadzor, Armenia. 1-6. GIN-1142/90-95, first lower molar, m1; 7-10. GIN-1142/96-99, first upper molar, M1; 11. GIN-1142/100, second lower molar, m2; occlusal view; a, alveolar view. All molars are shown as left side, numbers 1, 5, 7 are reversed. Scale equals $1 \mathrm{~mm}$.

Material. $3 \mathrm{~m} 1,3$ fragmentary $\mathrm{m} 1,1 \mathrm{~m} 2,3 \mathrm{M} 1,1$ fragmentary M1, GIN-1142/90-101.

Locality. Haykadzor, Armenia, early Middle Pleistocene

Measurements. See Table 9 for dimensions of $\mathrm{m} 1$. Description. The microtine vole with the transitional morphology between the Allophaiomys and Microtus conditions. Lower $\mathrm{m} 1$ with communicating T4-T5 ("Pitymys-rhombus") not completely disconnected from the anteroconid cap. The anterocond cap shows better developed lingual salient angle (LSA5) and incipient labial salient angle (BSA4). The relative length of anteroconid is on the average less than 50. Enamel differentiation is of positive type, though trailing edges are still quite thick. Lower $\mathrm{m} 2$ ( $(\mathrm{L}=1.42 ; \mathrm{W}=0.95$ ) shows communicating
T1-T2 and T3-T4 (Figure 15.11). First upper molars (L/W: $1.95 \times 1.12 ; 2.2 \times 1.17 ; 2.15 \times 1.2 ;-\times 1.2$ ) show initial signs of complication at posterior side of T4 in three of four specimens.

Comparison. The sample of microtoid vole from Haykadzor looks somewhat less advanced than so far described materials from Arapi Fm (Kazachii Post, Arapi 1 and 2, Airport) and from the upper Akhuryan basin (Krasar) in less complex anteroconid structure, and possibly in less differentiated enamel. This may be evidence of a slightly older age of the Haykadzor fauna or a difference in taxonomy. One of the well-described forms with similar morphology is Allophaiomys nutiensis from Early Pleistocene locality Valerot in France (Chaline, 1972). Another morphologically close

TABLE 9. Measurements and indices, m1, Microtus ex gr. nutiensis, Haykadzor.

\begin{tabular}{llcccccc}
\hline & $\mathbf{n}$ & Mean & SE & Min & Max & SD & CV \\
\hline L & 5 & 2.43 & 0.1164 & 2.1 & 2.8 & 0.2603 & 10.70 \\
W & 6 & 0.94 & 0.0420 & 0.78 & 1.07 & 0.1028 & 10.92 \\
A & 6 & 1.14 & 0.0670 & 0.9 & 1.4 & 0.1642 & 14.34 \\
A/L & 5 & 47.21 & 1.1965 & 42.86 & 50 & 2.6754 & 5.67 \\
BTQ & 5 & 75.03 & 4.8882 & 59.02 & 86.20 & 10.9303 & 14.57 \\
SDQ & 5 & 83.44 & 4.2994 & 67.82 & 93.08 & 9.6138 & 11.52 \\
\hline
\end{tabular}


form was described from late Early Pleistocene karstic site Monte Peglia in Italy (van der Meulen, 1973). Another similar form from a geographically close region was described as $M$. nutiensis from Early Pleistocene locality Dursunlu in central Turkey (Ünay, 1998). A single lower $\mathrm{m} 1$ of similar morphology was described as Allophaiomys cf. pliocaenicus from Pasinler A (Yaladag) locality in the neighbouring region of eastern Turkey (VasiIyan et al., 2014), in deposits malacologically similar to the Ani Fm underlying the Arapi Fm deposits. The sample from Haykadzor is obviously chronologically younger than all those forms, but somewhat dissimilar in less complicated and more assymetric anteroconid cap.

Comments. A transitional morphological stage of first lower molar in Microtini between the plesiomorphic condition with three closed triangles and broadly confluent anteroconid, known as the "Allophaiomys" condition (late Early Pleistocene), and the advanced stage with five closed triangles and a trifoliate anteroconid cap, called the "arvaloid" condition (late Middle Pleistocene to the Recent), are generally addressed as "Pitymys"-like stage. This transitional morphology is characterised by three closed triangles, two fused or incompletely closed triangles and rounded to slightly trifoliate anteroconid cap. Several evolutionary lineages of Microtini could pass this stage in late Early and early Middle Pleistocene thus obscuring the phyletic relationships of fossil forms. The morphology of the taxon "Allophaiomys nutiensis" is a good match for this intermediate stage but it could easily contain multiple unrelated forms. A thorough revision of this grade of Microtini from latest Early and early Middle Pleistocene of Europe and western Asia (e.g., samples attributed to $A$. nutiensis, M. thenii, M. hintoni, etc.) with accurate documentation of all molars of the toothrow and enamel differentiation quotent is needed.

The vole from Haykadzor may be related to Terricola, as suggested by morphotypes of $\mathrm{m} 1$ with "Pitymys-rhombus" (Figure 15.6), confluence pattern in m2, and incipient LSA4 in M1. It may show the way of transformation of Allophaiomys dental pattern into that of Terricola. The origin and early evolution of Terricola is still poorly known and generally related with Early Pleistocene Allophaiomys (Chaline, 1972; Rabeder, 1981; Rekovets and Nadachowski, 1995). The study of morphometry of lower $\mathrm{m} 1$ in Middle and Late Pleistocene subterranean voles in Europe put forward a hypothesis of the group affinity with Early Pleistocene Allophaiomys-grade Microtini as $A$. pitymyoides Chaline, $A$. nutiensis Chaline, A. praehintoni Rabeder (BrunetLecomte and Chaline, 1991). A credible hypothesis interpreting Allophaiomys laguroides Kormos from Early Pleistocene of Betfia 2 as an early stage of Terricola was proposed by Rekovets and Nadachowski (1995). Popular taxonomic practice relates primitive transitional stages of multiple lineages of Microtini (Microtus s.str., Terricola, Stenocranius, etc.) with confluent T4-T5 to Terricola. According to a widespread concept, the Middle and Late Pleistocene Terricola descended from early Middle Pleistocene Microtus arvalidens Kretzoi (e.g., Maul and Markova, 2007; Maul et al., 2007, etc.). Rekovets and Nadachowski (1995), though placed M.arvalidens in Terricola, argued against the direct phyletic connection of $M$. arvalidens and $T$. subterraneus. Indeed, the topotypic $M$. arvalidens ( $=M$. arvaloides Hinton) from Cromerian of West Runton (Maul and Parfitt, 2010) and large synchronous samples from Eastern Europe as Tikhonovka 1 in Ukraine (Rekovets and Nadachowski, 1995) and Port-Katon 4 (Tesakov et al., 2007) show a range of variation uncommon to later Terricola, and rather suggesting a phyletic link with Microtus arvalis s.I. In general, early Middle Pleistocene voles attributed throughout Europe to $M$. arvalidens are clearly heterogeneous, representing in different sites either an arvaloid Microtus (e.g., West Runton), true Terricola (e.g., Subpiatră: Hír and Venczel, 1992) or a mixture of different forms (e.g., Betfia 5: Kretzoi, 1941 and Terzea, 1970; Futjova Cave: Popov, 2017). Most Toringian records of M. arvalidens in Europe likely represent Terricola gr. subterraneus. A modern revision of the group is needed.

Genus PROLAGURUS Kormos, 1938

Prolagurus pannonicus transylvanicus Terzea, 1989

Figure 16.1-3

Material. $1 \mathrm{~m} 1,1$ fragmentary $\mathrm{m} 1,1 \mathrm{~m} 3,3 \mathrm{M} 1,1$ M2, GIN-1142/105-112.

Locality. Haykadzor, Armenia

Measurements. $m 1: L=2,25, W=0,87, A=1,15 ; m 1$ fragm.: $W=1.0 ; m 3: L=1.6, W=0.8 ; M 1 L, W: 1.9 x$ $1.0,1.95 \times 1.16 ; \mathrm{M} 2 \mathrm{~L}, \mathrm{~W}: 1.85 \times 1.12$.

Description. Lower m1 (Figure 16.1) has widely fused anteroconid triangles well-separated from rounded cap with a slightly expressed antero-labial reentrant (BRA4). This reentrant fold becomes deeper with wear (Figure 16.1a, viewed from alveolar side of the molar). The lagurine additional anteroconid tract is present on the labial side of the cap. The enamel band is positively differentiated. Three M1 show moderately developed lagurine 


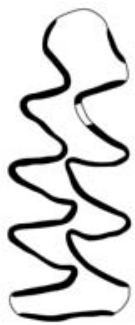

1

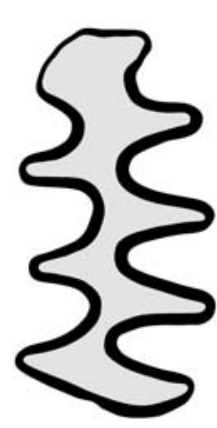

4

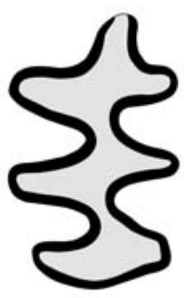

5

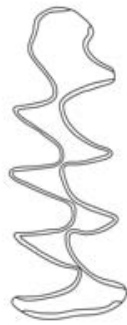

$1 \mathrm{a}$

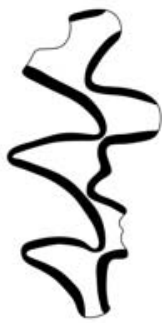

2

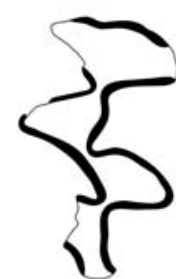

3

\section{$1 \mathrm{~mm}$}

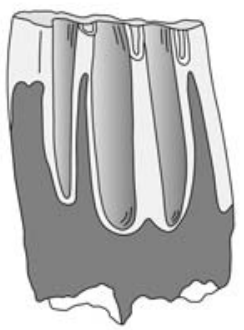

$4 a$

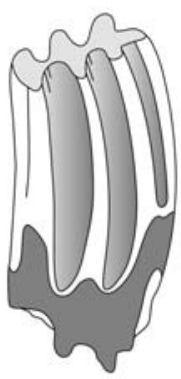

$5 a$

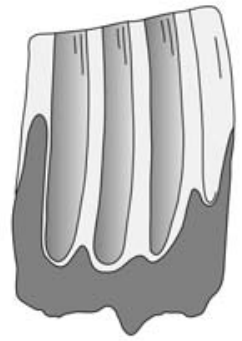

4b

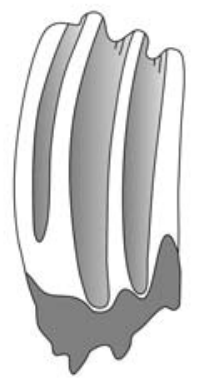

$5 b$
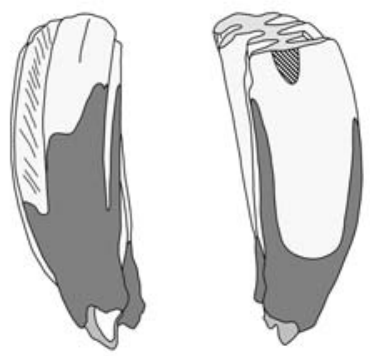

$4 c$

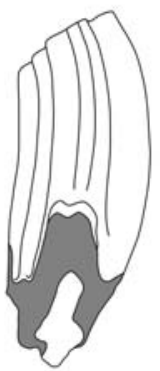

$5 c$
$4 d$

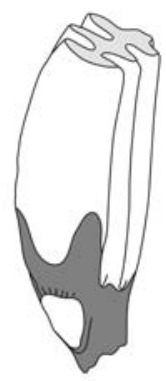

$5 d$

FIGURE 16. Dental morphology of the fossil voles from early Middle Pleistocene of Armenia. Prolagurus transylvanicus, Haykadzor. 1. GIN-1142/105, first lower molar, m1, right side; 1a, the same molar in occlusal view; 2 . GIN-1142/ 108, first upper molar, M1; 3. GIN-1142/111, second upper molar, M2; a, alveolar view. Ellobius pomeli (after Tesakov, 2016), 4. Krasar, GIN-1141/1, first lower molar, m1, left side; 5. Haykadzor, GIN-1142/1, second lower molar, m2, right side, occlusal view; $4 \mathrm{a}$ and $5 \mathrm{a}$, labial; $4 \mathrm{~b}$ and $4 \mathrm{~b}$, lingual; $4 \mathrm{c}$ and $5 \mathrm{c}$, anterior; $4 \mathrm{~d}$ and $5 \mathrm{~d}$, posterior view. Numbers 2 and 3 are reversed. Scale equals $1 \mathrm{~mm}$.

denticles (Figure 16.2). A single incompletely preserved specimen of $\mathrm{M} 2$ has a characteristic smooth lagurine denticle in the depth of the LRA2 (Figure 16.3).

Comments. The morphology of Prolagurus pannonicus Kormos from Haykadzor fits that of the sample from Kazachii Post, Arapi 1 and 2, and Airport sites of the Arapi Fm (Agadjanan and Melik-
Adamyan, 1985; Melik-Adamyan, 1994). This form is characterised by the rounded anteroconid cap with well developed antero-labial salient angle (BSA4) with lagurine tract. The evolutionary sequence of morphospecies in Pleistocene Prolagurus-Lagurus was established in numerous publications (e.g., Zazhigin, 1970; Markova, 1974; Rekovets and Nadachowski, 1995; Agadjanian, 
2009 , etc.). According to Rekovets and Nadachowski (1995), the lineage of rootless smaller lagurines includes Prolagurus ternopolitanus (earliest Biharian) with widely fused anteroconid cap and triangles, $P$. pannonicus (late early-early late Biharian) with dominant morphotype with broadly confluent anteroconid triangles separated from rounded cap, Lagurus transiens (late Biharian) with separated anteroconid triangles and slightly trifoliate cap, and $L$. lagurus (Toringian) with separated anteroconid triangles and strongly trifoliate cap. For advanced $P$. pannonicus of late Early to early Middle Pleistocene with anteroconid cap showing incipient labial reentrant (BRA4) Terzea (1989) described the species $P$. transylvanicus. We follow Rekovets and Nadachowski (1995) in its subspecies rank, $P$. pannonicus transylvanicus. This taxon is a perfect taxonomic and chronological match for the lagurine from Armenia.

\section{Genus ELLOBIUS Fischer, 1814 \\ Subgenus BRAMUS Pomel, 1892 \\ Ellobius pomeli Tesakov, 2016 \\ Figure 16.4-5}

Material. $1 \mathrm{~m} 1$, GIN-1141/1; 1m2, GIN-1142/2.

Locality. Krasar (m1), Haykadzor (m2).

Measurements. $\mathrm{m} 1 \mathrm{~L}=2.8, \mathrm{~W}=1.35, \mathrm{~A}=1.15, \mathrm{H}$ $=2.9, \mathrm{R}=1.25, \mathrm{ASD}=2.3, \mathrm{MIM}=2.4, \mathrm{HSD}=2.32$, $\mathrm{HSLD}=2.25$, Lbas $=3.1, \mathrm{HH}$-index $=3.23 ; \mathrm{m} 2: \mathrm{L}=$ 2.0, $\mathrm{W}=1.16, \mathrm{H}=1.55, \mathrm{R}=1.0, \mathrm{ASD}=1.2, \mathrm{HSD}=$ 1.05, HSLD = 1.1, Lbas $=2.3, \mathrm{HH}$-index $=1.52$.

Description. The morphologically archaic mole vole intermediate in hypsodonty stage between mid Early Pleistocene (early-mid Calabrian) Ellobius tarchancutensis Topachevsky from Crimea and lower Don River area and late Middle Pleistocene to Recent southern mole vole E. lutescens Thomas of Transcaucasus, Near East and eastern Anatolia (see the details in Tesakov, 2016).

Comments. The hypsodonty of $\mathrm{m} 2$ from Haykadzor looks slightly less advanced than in $\mathrm{m} 1$ from Krasar. Although the variability range of hypsodonty features is not known for $E$. pomeli, the observed difference may account for somewhat older geological age of the Haykadzor fauna relative to the Krasar assemblage also suggested by morphology of Microtini voles in both localities.

\section{BIOCHRONOLOGY}

The composition of the Haykadzor fauna, the fauna of Krasar (Trifonov et al., 2016) and other published faunas of the Arapi Fm near Gyumri (Agadjanyan and Melik-Adamyan, 1985, 2016; Melik-Adamyan, 1985, 1994, 2003, 2004, 2017) represents a compact assemblage of small mammals (Table 10).

The faunal assemblage of the Arapi Fm clearly indicates a broadly synchronous fauna of early Middle Pleistocene age. Geologically it is bracketed by the Matuyama-Brunhes reversal at the bottom $(0.78 \mathrm{Ma})$ and the Arvicola datum estimated as ca.0.5-0.6 Ma (von Koenigswald, van Kolfschoten, 1996; Maul et al., 2000) from above. The evolutionary level of Mimomys intermedius from Haykadzor is comparable to populations of

TABLE 10. Composition of early Middle Pleistocene small mammal faunas of north-western Armenia.

\begin{tabular}{|c|c|c|c|c|c|c|c|}
\hline \multirow[b]{2}{*}{ Taxa } & \multicolumn{7}{|c|}{ Localities } \\
\hline & 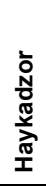 & 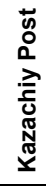 & $\begin{array}{l}n \\
\\
\frac{\pi}{\pi} \\
\frac{\pi}{\alpha}\end{array}$ & $\begin{array}{l}\text { 눙 } \\
\frac{0}{0} \\
\frac{0}{0} \\
\frac{0}{\alpha}\end{array}$ & 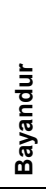 & 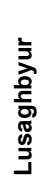 & 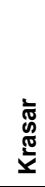 \\
\hline Sorex sp. & - & + & - & - & - & - & - \\
\hline Sorex cf. runtonensis & + & - & - & - & - & - & - \\
\hline Neomys cf. hintoni & + & - & - & - & - & - & - \\
\hline Ochotona sp. & - & - & - & - & - & - & + \\
\hline Ellobius pomeli & + & - & - & - & - & + & + \\
\hline Mimomys intermedius & + & + & - & - & - & - & - \\
\hline Microtus ex gr. nutiensis & + & - & - & - & - & - & - \\
\hline Terricola sp. & - & + & + & + & - & + & + \\
\hline $\begin{array}{l}\text { Prolagurus pannonicus } \\
\text { transylvanicus }\end{array}$ & + & + & + & + & + & + & - \\
\hline Eolagurus sp. & - & + & - & + & - & - & - \\
\hline
\end{tabular}


water vole from Cromerian correlated deposits of Western and Eastern Europe with values of size and hypsodonty indicating an early part of early Middle Pleistocene. Prolagurus pannonicus transylvanicus from the Arapi Fm precisely coincides in its evolutionary level with lagurines of late Early early Middle Pleistocene faunas of Eastern and Central Europe. Smaller lagurines of Tiraspolian faunal complex of Eastern Europe (ca. 0.8-0.6 Ma) show the evolutionary transition from $P$. pannonicus dominated morphotypes in early Tiraspolian faunas to Lagurus transiens dominated morphotypes in latest Tiraspolian assemblages (Agadjanian, 2009). In biozonal chart of Eastern Europe (Vangengeim et al., 2001) this corresponds to the upper part of zone MQR7 (concurrent range zone of Prolagurus pannonicus and Stenocranius hintoni), spanning the very beginning of the early Middle Pleistocene. It is thus possible to correlate the faunas of the Arapi Fm to early Tiraspolian faunal complex. The yellow lagurine, Eolagurus sp. (cf. argyropuloi Gromov and Parfenova) also matches the evolutionary level of the Tiraspolian faunas of Eastern Europe. Subterranean voles Terricola of the Upper Akhuryan basin (Krasar) show a primitive evolutionary stage, clearly more primitive than recent and mid Middle Pleistocene Terricola species from the Caucasus. Microtus gr. nutiensis from Arapi Fm (Haykadzor) belongs to a morphological grade common in Europe at latest Early and early Middle Pleistocene. The same intermediate evolutionary position between Early Pleistocene and late Middle to Late Pleistocene and Recent forms occupies the mole vole Ellobius pomeli from the Arapi and synchronous deposits of western Armenia. Having in mind also absolute dates of 0.6-0.7 Ma obtained from Aragats ashes overlying and interfingering with Arapi deposits, their normal polarity interpreted as Bruhnes Chron, considered together with the evolutionary level of arvicolines from this formation, the age of the Arapi deposits and faunas can be reliably dated in the range of 0.78-0.6 Ma. In this range, a correspondence to a glacial/interglacial stage cannot be defined with certainty yet. Nevertheless, the notable arid elements in pollen flora and small mammals may favour a correlation to a glacial time, with MIS18 and, less likely, MIS16 being plausible time matches.

Combined biotic, paleomagnetic, and radiometric control makes the studied biotic sequence a reference point for the knowledge of geological, paleoclimatic, and biological evolution of the southern Caucasus in the Quaternary.

\section{PALAEOENVIRONMENT}

The available biotic record from fluvial formations of western Armenia enables a synthetic overview of the environmental conditions of regional late Early to early Middle Pleistocene transition.

Palynological data from diatomaceous clays of the Ani Fm indicate forest-steppe landscapes with more forested phases and a general trend towards more open biotopes in the Arapi time. Data on Pleistocene diatom assemblages of the Shirak Depression was obtained from the lacustrine diatomaceous deposits of the Ani unit in the sections of Arapi and the Marmashen borehole 6 (Zaikina et al., 1969a, b.). Later, additional material was studied in the Ani sections of Haykavan (lower part) and Arapi deposits of the Haykadzor section (beds 6-7) (Shalaeva et al., 2019). The general revealed trend is from assemblages with higher representation of planktonic forms in lower parts of the Ani Fm towards associations with growing role of bottom and littoral forms higher in the Ani sequences and in the Arapi Fm. This picture supports a concept of a progressing shallowing of the Pleistocene Shirak Lake (Sayadyan, 2009; Shalaeva et al., 2019) from late Early to early Middle Pleistocene. Molluscan and fish assemblages indicate conditions of a large lake with rich aquatic vegetation and a varying depth. Small mammalian fossils from the Arapi Fm indicate open steppe-like landscapes (lagurines, pika), meadows (mole voles, subterranean voles, Sorex), and periaquatic (ancient water voles Mimomys intermedius, water shrew) biotopes. The differences in composition of the Arapi faunas (e.g., dominant Mimomys in Haykadzor versus prevailing lagurines in Kazachii Post) can reflect both local taphonomy and/or environmental oscillations. The important role of small mammals adapted to open, arid biotopes in the Arapi sites can be an indication of a glacial climatic stage as the time of deposition of this unit.

\section{DISCUSSION AND CONCLUSIONS}

Palynological data on the lacustrine deposits of the Ani Fm indicate extensive development of forest-steppe and steppe coenoses in the Shirak Depression grading into birch forest and steppe associations in Arapi time (Figure 3). The reconstructed landscape trend in the range of ca. 1.5-0.6 Ma features the general transition from foreststeppe to steppe conditions. The high number of "exotic" arboreal species (not currently occurring in the Shirak region) in the Ani deposits, like Tsuga spp., Podocarpus, Cedrus, Abies alba, Taxus, Liq- 
uidambar, Altingia, Castanea, Carya (Figure 4), does not contradict to the late Early Pleistocene early Middle Pleistocene age of the main stage of the ancient Shirak lacustrine-fluvial sedimentary sequence.

The association of malacofauna from the Arapi unit exclusively contains Recent limnic species and can hardly be older than Middle Pleistocene. The Ani mollusc fauna is represented mainly by extinct fresh water species. This testifies that the Ani fauna is older and belongs to Calabrian and, perhaps, the lowest Middle Pleistocene. The hydrobiid Falsipyrgula of the Ani molluscan fauna sheds light on the historical biogeography and dispersal routes of freshwater fauna in the region. Falsipyrgula has a Ponto-Caspian origin, as shown by Wilke et al., 2007, based on the extant endemic Falsipyrgula pfeiferi (Weber, 1927) occurring in western Taurus Lake District. The migration pathways of the freshwater Ponto-Caspian fauna in this region are still controversial. For forms of the genus Dreissena, a Pliocene colonisation from Mesopotamia via central Anatolian lake area is inferred (Wilke et al., 2007). Finds of Falsipyrgula in Early Pleistocene of Armenia and Eastern Turkey (Vasilyan et al., 2014) show the probable migration routes of this genus through the earlymiddle Pleistocene lake systems of the Western Caucasus and Eastern Turkey, and also suggest an earlier divergence from the Ponto-Caspian genera Euxinipyrgula, Turricaspia, and 'Micromelania' than the estimate of $0.42 \pm 0.18$ Ma suggested by Wilke et al. (2007).

The fish material from two sites of the Arapi Fm (Lusaghbyur and Haykadzor) provides evidence of a depleted cyprinid community dominated by the Barbinae (Capoeta sp., scraper) and Pseudalburnus sp., whereas the Leuciscinae (Telestes cf. souffia), documented by pharyngeal teeth, is extremely rare. This assemblage characterises the lacustrine and river habitats with rocky bottom, well-warmed coastal zone, and the presence of intensive fouling produced by water vegetation. Occurrence of the above-listed taxa points to the continuity of the local ichthyofauna with the earlier Plio-Pleistocene fish communities known from Armenia (Bogachev, 1938; Vasilyan, 2008 a, b).

The mammalian faunas of Haykadzor and Krasar contribute to the knowledge of biodiversity and refines the biostratigraphic position of the Gyumri faunal complex.

Combined biotic, paleomagnetic, and radiometric control makes the studied biotic sequence a reference point for the knowledge of geological, paleoclimatic, and biological evolution of the southern Caucasus, and the entire Ponto-Caspian region in the Quaternary.

\section{ACKNOWLEDGEMENTS}

The work was financially supported by the Russian Foundation for Basic Research, projects no. 18-05-00746 (paleontological work of AT, AS, PF), 18-00-00977 (paleoenvironmental study of Early and Middle Pleistocene of Transcaucasus), 17-05-00727 (regional stratigraphy and geochronology), 15-55-05009 (fieldwork and sampling), 1904-00514 (paleontological work of ES). The study corresponds to the plan of scientific research of the Geological Institute of the Russian Academy of Sciences, Paleontological Institute of the Russian Academy of Sciences, Zoological Institute of the Russian Academy of Sciences, and V.S. Sobolev Institute of Geology and Mineralogy of the Siberian Branch of the Russian Academy of Sciences. The comments of two anonymous reviewers, and the third reviewer, F.P. Wesselingh, helped to improve the manuscript and are gratefully acknowledged. D.M. Palatov is thanked for the invaluable assistance in systematics and taxonomy of small bivalves.

\section{REFERENCES}

Abich, H. 1859. Vergleichende chemische Untersuchungen der Wasser des Caspischen Meeres, Urmia und Van-See's. Mémoires de l'Académie Impériale des Sciences de St. Pétersbourg, 6, 1(7):1-59.

Agadjanian, A.K. 2009. Pliocene-Pleistocene Small Mammals of the Russian Plain. Nauka, Moscow. (In Russian)

Agadjanyan, A.K. and Melik-Adamyan, G.U. 1985. Early Pleistocene small mammals in the Shirak Basin of Armenia. Bulletin of Commission for Study of Quaternary, 54:91-100. (In Russian) 
Agadjanyan, A.K. and Melik-Adamyan, G.U. 2016. First record of fossil mole vole from Lower Neopleistocene of the Shirak Depression in Armenia. In Theriofauna of Russia and Adjacent Territories. International Conference. X Congress of the Russian Theriological Society RAS. KMK Scientific Press, Moscow. (In Russian)

Agajanian, A.K. and Kondrashov, P.E. 2007. Mollusks and small mammals from the Kuznetsovka locality, Pleistocene of the Oka-Don Plain. Paleontological Journal, 41(4):395-406. https:// doi.org/10.1134/S0031030107040053

Akramowski, N.N. 1956. Pleistocene fresh-water molluscs from sand quarry near Leninakan. Izvestiya (Proceedings) of the Academy of Sciences of the Armenian SSR, Biological and Agricultural Sciences, 9(1):81-90. (In Russian)

Akramowski, N.N. 1976. Fauna of Armenian SSR: Molluscs (Mollusca). Academy of Sciences of Armenian SSR, Yerevan. (In Russian)

Alekseeva, L.I. 1977. Early Anthropogene Theriofauna of Eastern Europe. Nauka, Moscow. (In Russian)

Anistratenko, V., Peretolchina, T., Sitnikova, T., Palatov, D., and Sherbakov, D. 2017. A taxonomic position of Armenian endemic freshwater snails of the genus Shadinia Akramowski, 1976 (Caenogastropoda: Hydrobiidae): combining morphological and molecular evidence, Molluscan Research, 37(3):212-221. https://doi.org/10.1080/ 13235818.2017.1279477

Anistratenko, V.V. 2008. Evolutionary trends and relationships in hydrobiids (Mollusca, Caenogastropoda) of the Azov-Black Sea Basin in the light of their comparative morphology and paleozoogeography. Zoosystematics and Evolution, 84(2):129-142. https://doi.org/ 10.1002/zoos.200800001

Arakelyan, M.S., Danielyan, F.D., Corti, C., Sindaco, R., and Leviton, A.E. 2011. Herpetofauna of Armenia and Nagorno-Karabakhkh. Society for the Study of Amphibians and Reptiles. Society for the Study of Amphibians and Reptiles, Salt Lake City.

Avakyan, L.A. 1957. Quaternary fossil mammals of Armenia. Izvestiya (Proceedings) of the Academy of Sciences of the Armenian SSR, Geology and Geography Series, 10(4):13-22. (In Russian)

Avakyan, L.A. 1959. Quaternary Mammalian Fauna in Armenia. Academy of Sciences of the Armenian SSR, Yerevan. (In Russian)

Ayvazyan, A., Vasilyan, D., and Böhme, M. 2018. 3D morphology of pharyngeal dentition of the genus Capoeta (Cyprinidae). Implications for taxonomy and phylogeny. Journal of Zoological Systematics and Evolutionary Research. 57:179-190. https://doi.org/10.1111/jzs.12217

Azzaroli, A. 1987. On the occurrence of Equus stenonis in China. Bollettino della Società Paleontologica Italiana, 25(2):199-201.

Azzaroli, A. 1982. On Villafranchian Palaearctic Equids and their allies. Palaeontographia Italica, 72:74-97.

Azzaroli, A. 1983. Quaternary mammals and the "End-Villafranchian" dispersal event-turning point in the history of Eurasia. Palaeogeography, Palaeoclimatology, Palaeoecology, 44:117139. https://doi.org/10.1016/0031-0182(83)90008-1

Baryshnikov, G.F. and Baranova, G.I. 1983. Rodents of the Early Paleolithic in the Greater Caucasus. Proceedings of Zoological Institute of the Russian Academy of Sciences, 119:100-138. (In Russian)

Bleeker, P. 1859. Enumeratio specierum piscium hucusque in Archipelago Indico observatarum. Acta Societatis scientiarum Indo-Neerlandae, 6:1-279.

Boettger, O. 1881. Sechtes Verzeichnis transcaucasischer, armenischer und nordpersischer Mollusken. Jahrbücher der Deutschen Malakozoologischen Gesellschaft, 8:167-261.

Bogachev, V.V. 1938. Fauna of diatom Pliocene sediments in Transcaucasia. Proceedings of Azerbaijan Branch of the USSR Academy of Sciences. Baku. Geological Series, 9(39):61-82. (In Russian)

Bolkay, St. J. 1919. Osnove uporedne osteologije anurskih batrachija sa dodatkom o porijeklu Anura i sa skicom naravnog sistema istih. Glasnik Zemaljskog Muzeja Bosni Hercegovini, 31:353-377.

Bonaparte, C. L., 1835. Prodromus systematis ichthyologiae. Nuovi Annali delle Scienze Naturali Bologna, Ser. 1., Ann. 2, 4:181-196, 272-277.

Bonaparte, C.L. 1837. Iconografia della fauna italica per le quattro classi degli animali vertebrati. Pesci. Roma. T. III. Fasc. 19-21:94-103, 105-109. 
Bonaparte, C.L. 1845a. Specchio generale del sistema mastozoologico, p.323-356. In Atti Della Sesta Riunione Degli Scienziati Italiani Tenuta in Milano nel Settembre del 1844. Luigi di Giacomo Pirola, Milano.

Bonaparte, C.L. 1845b. Catalogo Metodico dei Mammiferi Europei. Luigi di Giacomo Pirola. Milano.

Boulenger, G.A. 1885. Description of a new species of frog from Asia Minor. Proceedings of the Zoological Society of London, 53(1):22-23. https://doi.org/10.1111/j.10963642.1885.tb02882.x

Bowdich, T. E. 1821. An Analysis of the Natural Classifications of Mammalia for the Use of Students and Travellers. J. Smith, Paris.

Böhme, G. 1977. Zur Bestimmung quartärer Anuren Europasan Hand von Skelettementen. Wissenschaftliche Zeitschrift der Humboldt-Universität zu Berlin, MatematischNaturwissenschaftliche Reihe, 26(3):283-300.

Brunet-Lecomte, P. and Chaline, J. 1991. Morphological evolution and phylogenetic relationships of the European ground voles (Arvicolidae, Rodentia). Lethaia, 24:45-53. https://doi.org/ 10.1111/j.1502-3931.1991.tb01179.x

Chaline, J. 1972. Les Rongeurs du Pléistocene Moyen et Supérieur de France. SNRS, Paris.

Chochieva, Yu.l. 1999. Temps of extinction of conifers in Meso-Cenozoic of Georgia. Problems of Paleobiology. Tbilisi, 1:27-45. (In Russian)

Cocchi, I. 1867. L'uomo fossile nell'Italia centrale. Studj paleoetnologici. Memorie della Società Italiana Scienze Naturali, 2(7):1-80.

Cuvier, G. and Valenciennes, A. 1842. Histoire naturelle des poissons, 16. Chez F. G. Levrault. Paris.

De Giuli, C. 1972. On the type form of Equus stenonis Cocchi. Palaeontographia Italica, 68:3549.

De Giuli, C. 1986. Late Villafranchian faunas of Italy:the Selvella Local Fauna in the southern Chiana Valley. Palaeontographia Italica, 74:11-50.

Eisenmann, V. 1981. Etude des dents jugales inférieures des Equus (Mammalia, Perissodactyla) actuels et fossils. Palaeovertebrata, 10(3-4):127-226.

Ellerman, J.R. and Morrison-Scott, T.C.S. 1966. Checklist of Palaearctic and Indian Mammals 1758 to 1946. 2nd edition. British Museum (Natural History), London.

Fatio, V. 1867. Les campagnols du bassin du Léman. Georg, Paris.

Filippova, N.Yu. 1997. Palynology of the Upper Pliocene to Middle Pleistocene in the Southern Part of the Caspian Region. Geos, Moscow. (In Russian)

Fischer, G. 1813. Zoognosia Tabulis Synopticis Illustrata, in Usum Praelectionum Academiae Imperialis Medico-Chirurgicae Mosquensis Edita, $3^{\text {rd }}$ ed., vol.1. Nicolai Sergeidis Vsevolzsky, Moscow.

Fischer, G. 1814. Zoognosia tabulis synopticis illustrata. Quadrupedum reliquorum, cetorum et montrymatum descriptionem continens. $3^{\text {rd }}$ ed., vol.2. Nicolai Sergeidis Vsevolozsky, Moscow.

Fischer, G. 1817. Adversaria zoological fasciculus primus. Mémoires de la Société Impériale des Naturalistes de Moscou, 5:357-428.

Foronova, I.V. 1990. Fossil Horses of the Kuznetsk Depression. Institute of geology and geophysics of the Siberian Branch of the USSR Academy of Sciences, Novosibirsk. (In Russian)

Foronova, I.V. 1998. Early Quaternary mammals from the Kuznetsk Basin, south of western Siberia. Mededelingen Nederlands Instituut voor Toegepaste Geowetenschappen TNO, 60:353-374.

Foronova, I.V. 2001. Quaternary Mammals of the South-East of Western Siberia (Kuznetsk Basin): Phylogeny, Biostratigraphy, and Palaeoecology. Siberian Branch of the Russian Academy of Sciences, GEO, Novosibirsk. (In Russian)

Forsten, A. 1986. A review of the Süssenborn horses and the origin of Equus hydruntinus Regalia. Quartärpaläontologie, 6:43-52.

Forsten, A. 1999. A review of Equus stenonis Cocchi (Perissodactyla, Equidae) and related forms. Quaternary Science Reviews, 18:1373-1408. https://doi.org/10.1016/S02773791(98)00073-0

Gabrielyan, I., Roiron, P., Gasparyan, B., Chataigner, C., Nahapetyan, S., Ollivier, V., Bruch, A., Pipoyan, S., and Marjanyan, M. 2004. The palaeoenvironment of the Vorotan River basin (Republic of Armenia) in Pliocene-Pleistocene (on materials of Shamb Subgroup localities of 
flora and fauna), p. 44-46. In International Scientific Conference. Archeology, Ethnology and Folklore Studies of Caucasus. Nekeri, Tbilisi. (In Russian)

Gabunia, L.K. and Vekua, A.K. 1989. Anthropogene Horses of Georgia. Metsniereba, Tbilisi (In Russian)

Glöer P., Bößneck U., Walther F., and Neiber, M.T. 2016. New taxa of freshwater molluscs from Armenia (Caenogastropoda: Truncatelloidea: Hydrobiidae). Folia Malacologica, 24(1):3-8.

Gray, J.E. 1821. On the natural arrangement of vertebrose animals. London Medical Repository, 15:296-310.

Gray, J.E. 1825. A synopsis of the genera of reptiles and Amphibia, with a description of some new species. Annals of Philosophy, Series 2, 10:193-217.

Gevorgyan, H., Repstock, A., Schulz, B., Meliksetian, K., Breitkreuz, C., and Israyelyan, A. 2018. Decoding a post-collisional multistage magma system: The Quaternary ignimbrites of Aragats stratovolcano, western Armenia. Lithos, 318-319:267-282. https://doi.org/10.1016/ j.lithos.2018.07.02410.1016/j.lithos.2018.07.024

Gromova, V.I. 1949. The history of horses (genus Equus) in the Old World. Trudy of Paleontological Institute of the USSR Academy of Sciences, Volumes 1 and 2. (In Russian)

Hammer, Ø., Harper, D.A.T., and Ryan, P.D. 2001. PAST: Paleontological statistics software package for education and data analysis. Palaeontologia Electronica, 4.1.4:1-9. http:// palaeo-electronica.org/2001_1/past/issue1_01.htm

Heinrich, W.-D. 1982. Zur Evolution und Biostratigraphie von Arvicola (Rodentia, Mammalia) im Pleistozän Europas. Zeitschrift für Geologische Wissenschaften, 10(6):683-785.

Hinton, M.A.C. 1911. The British fossil shrews. Geological Magazine London, 8(12):529-539.

Hinton, M.A.C. 1910. A preliminary account of the British fossil voles and lemmings with some remarks of the Pleistocene climate and geography. Proceedings of the Geological Association of London, 21:489-507.

Hír, J. and Venczel, M. 1992. The Arvicolids (Rodentia, Mammalia) of the lower Pleistocene vertebrate fauna of Subpiatră, W-Romania. Nymphaea, 22:75-91.

Jenyns, L. 1832. A monograph of the British species of Cyclas and Pisidium. Transactions of the Cambridge Philosophical Society, 4(2):289-312.

Joannin, S., Cornée, J.-J., Münch, P., Fornari, M., Vasiliev, L., Krijgsman, W., Nahapetyan, S., Gabrielyan, I., Ollivier, V., Roiron, P., and Chataigner, C. 2010. Early Pleistocene climatic cycles in continental deposits of the Lesser Caucasus of Armenia inferred from palynology, magnetostratigraphy, and ${ }^{40} \mathrm{Ar} /{ }^{39} \mathrm{Ar}$ dating of volcanic tuffs. Earth and Planetary Science Letters, 291:149-158. https://doi.org/10.1016/j.epsl.2010.01.007

Kandel, A.W., Gasparyan, B., Allué, E., Bigga, G., Bruch, A.A., Cullen, V.L., Frahm, E., Ghukasyan, R., Gruwier, B., Jabbour, F., Miller, C.E., Taller, A., Vardazaryan, V., Vasilyan, D., and Weissbrod, L. 2017. The earliest evidence for Upper Paleolithic occupation in the Armenian Highlands at Aghitu-3 Cave. Journal of Human Evolution, 110:37-68. https:// doi.org/10.1016/j.jhevol.2017.05.010

Kaup, J.J. 1829. Skizzirte Entwickelungs-Geschichte und natürliches System der Europäischen Thierwelt. C.W. Leske, Darmstadt.

Kinkelin, F. 1884. Die Schleussenkammer von Frankfurt-Niederrad und ihre Fauna. Bericht über die Senckenbergische Naturforschende Gesellschaft in Frankfurt am Main, 219-257.

Kormos, T. 1938. Mimomys newtoni F.Major und Lagurus pannonicus Kormos, zwei gliechzeitige verwandte Wuhlmause von verschiedener phylogenetischer Entwicklung. Anzeiger Ungarns Akademie Wissenschaften. Mathematisch-naturwissenschaftliche Klasse, 57:353-379.

Kozhamkulova, B.S. 1967. The complexes of Anthropogene mammals of Kazakhstan. Izvestiya of the Academy of Sciences of Kazakhstan SSR, Geology Series, 3:25-32. (In Russian)

Kretzoi, M. 1938. Die Raubtiere von Gombaszög nebst einer Übersicht der Gesamtfauna. (Ein Beitrag zur Stratigraphie des Altquartaers.). Annales Historico-Naturales Musei Nationalis Hungarici, 31:88-157.

Kretzoi, M. 1941. Die unterpleistozäne Säugetierfauna von Betfia von Nagyvárad. Földtany Közlöny, 71(7-12):235-261, 308-335.

Kretzoi, M. 1958. New names for Arvicolid homonyms. Annales Historico-Naturales Musei Nationalis Hungarici, Series Nova, 50(9):55-58.

Kryštufek, B. and Vohralík, V. 2005. Mammals of Turkey and Cyprus. Rodentia I: Sciuridae, Dipodidae, Gliridae, Arvicolinae. Univerza na Primorskem. Koper.

Kuzmin, S.L. 2012. Amphibians of the Former USSR. KMK, Moscow. (In Russian) 
Küster, H.C. 1852. Die Gattungen Paludina, Hydrocaena und Valvata. Systematisches Conchylien Cabinet von Martini und Chemnitz. Bauer und Raspe, Nurnberg.

Lamarck, J.B.P.A. de M. 1818. Histoire Naturelle des Animaux sans Vertèbres. Vol. 5. A. Belin, Paris.

Laurenti, J.N. 1768. Specimen Medicum, Exhibens Synopsin Reptilium Emendatum cum Experimentis Circa Venena et Antidota Reptilium Austriacorum. Joan. Thom. nob. de Trattnern, Wien.

Linnaeus, C. 1758. Systema Naturae, 10th ed. Laurenti Salvii, Stockholm.

Lozano-Fernández, I., Cuenca-Bescós, G., Blain, H.-A., López-García, J. M., and Agustí, J. 2013a. Mimomys savini size evolution in the Early Pleistocene of south-western Europe and possible biochronological implications. Quaternary Science Reviews, 76:96-101. https:// doi.org/10.1016/j.quascirev.2013.06.029

Lozano-Fernández, I., Agustí, J., Cuenca-Bescós, G., Blain, H.-A., López-García, J.M., and Vallverdú, J. 2013b. Pleistocene evolutionary trends in dental morphology of Mimomys savini (Rodentia, Mammalia) from Iberian peninsula and discussion about the origin of the genus Arvicola. Quaternaire, 24(2):179-190.

Major, F. 1902. Exhibition on, and remarks upon some jaws and teeth of Pliocene voles (Mimomys gen. nov.). Proceedings of the Zoological Society of London, 1(10):102-107.

Markova, A.K. 1974. Data on dental morphology of fossil lagurines Rodentia Microtinae (by example of the records from the Dnieper Riper region). Bulletin of Commission for Study of Quaternary, 41:107-120. (In Russian)

Martínková, N., Zima, J., Jaarola, M., Macholán, M., and Spitzenberger, F. 2007. The origin and phylogenetic relationships of Microtus bavaricus based on karyotype and mitochondrial DNA sequences. Folia Zoologica, 56:39-49.

Maul, L., Heinrich, W.-D., Parfitt, S., and Paunescu, A.-C. 2007. Comment on the correlation between magnetostratigraphy and the evolution of Microtus (Arvicolidae, Rodentia, Mammalia) during the Early and early Middle Pleistocene. Courier Forschungsinstitut Senckenberg, 259:243-263.

Maul, L. and Markova, A.K. 2007. Similarity and regional differences in Quaternary arvicolid evolution in Central and Eastern Europe. Quaternary International, 160:81-99. https://doi.org/ 10.1016/j.quaint.2006.09.010

Maul, L. and Parfitt, S. 2010. Micromammals from the 1995 Mammoth Excavation at West Runton, Norfolk, UK: Morphometric data, biostratigraphy and taxonomic reappraisal. Quaternary International, 228:91-115. https://doi.org/10.1016/j.quaint.2009.01.005

Maul, L., Rekovets, L.I., Heinrich, W.-D., Keller, T., and Storch, G. 2000. Arvicola mosbachensis (Schmidtgen 1911) of Mosbach 2: A basic sample for the early evolution of the genus and a reference for further biostratigraphical studies. Senckenbergiana lethaea, 80(1):129-147.

Mchedlishvili, N.Sh. 1984. The Genus Tsuga Carr. in Pliocene and Pleistocene of Western Georgia. Metsniereba, Tbilisi. (In Russian)

Méhely, L. v. 1914. Fibrinae Hungariae: Der tertiären and quartären wurzelzänigen Wühlmäuse Ungarns. Annales Historico-Naturales Musei Nationalis Hungarici, 12:155-243.

Melik-Adamyan, G.U. 1985. Fossil fauna of small mammals and its stratigraphic significance for Plio-Pleistocene deposits of Armenian SSR. Izvestiya (Proceedings) of the Academy of Sciences of Armenian SSR, Earth Sciences, 38(1):3-10 (In Russian)

Melik-Adamyan, G.U. 1994. On the upper biostratigraphic boundary of ignimbrites of the KasakhPambak type in Armenia. Izvestiya (Proceedings) of the National Academy of Sciences of Armenia, Earth Sciences, 47(3):9-12. (In Russian)

Melik-Adamyan, G.U. 2003. Stratigraphy and Paleogeography of Pliocene and Lower Neopleistocene of Central and Northwestern Armenia Based on Fauna of Land Vertebrates. Abridged thesis. Cand. Sci., Institute of Geological Sciences of the National Academy of Sciences of Armenia, Yerevan. (In Russian)

Melik-Adamyan, G.U. 2004. Stratigraphic significance of the Neopleistocene theriofauna of the Shirak depression. Izvestiya (Proceedings) of the National Academy of Sciences of Armenia, Earth Sciences, 57(3):27-31. (In Russian)

Melik-Adamyan, G.U. 2016. Geochronology of some Quaternary effusives of Armenia in the light of the joint analysis of recent radioisotopic, paleomagnetic and biostratigraphic data, p. 109111. In Voitekhovsky, Yu. L. (ed.), Regional Geology, Mineralogy, and Mineral Resources of the Kola Peninsula. Proceedings of the XIII all-Russian Fersman Scientific Conference. 
Geological Institute of the Kola Scientific Centre of the Russian Academy of Sciences, Apatity. (In Russian)

Melik-Adamyan, G.U. 2017. Yellow lagurines Argyropulo, 1946 (Rodentia, Mammalia) from early Neopleistocene deposits of northern Armenia, p. 195-197. In Materials of LXIII Session of Paleontological Society of the Russian Academy of Sciences. All-Russian Geological Institute (VSEGEI), Saint-Petersburg. (In Russian)

Melik-Adamyan, G.U., Kurochkin, E.N., and Chkhikvadze, V.M. 1988. New data on the Nurnus Pliocene fauna in Armenia and description of extinct subspecies of Caspian turtle. Vestnik Zoologii. 6:71-74 (In Russian)

Miller, G.S. 1912. Catalogue of the Mammals of Western Europe. British Museum of Natural History, London.

Musil, R. 1969. Die Equidenreste aus dem Pleistozän von Süssenborn bei Weimar. Paläontologische Abhandlungen A, 3(3-4):317-364.

Müller, O.F. 1774. Vermium Terrestrium et Fluviatilium seu Animalium Infusoriorum, Helminthicorum et Testaceorum, Non Marinorum, Succincta Historia, 1(2). Heineck et Faber, Kopenhagen - Leipzig.

Nesti, F. 1825. Sulla nuova specie di elefante fossile del Valdarno all' Illustrissimo sig. Dott. Prof. Ottaviano Targioni Tozzetti (Lettere sopra alcune ossa fossili del Valdarno non per anco descritte). Nuovo Giornale di Letterati, 11 (24):195-216.

Newton, E.T. 1881. Notes on the vertebrata of the pre-glacial Forest Bed Series of the East of England. Rodentia and Insectivora. Geological Magazine. London, 2(8):236-259.

Newton, E.T. 1882. The vertebrata of the Forest Beds Series of Norfolk and Suffolk. Memoirs of the Geological Survey of England and Wales, London.

Owen, R. 1846. A History of British Fossil Mammals and Birds. Van Voorst, London.

Owen, R. 1848. Description of teeth and portions of jaws in two extinct anthracotheroid quadrupeds (Hyopotamus vectianus and Hyop. bovinus) discovered by the Marchioness of Hastings in the Eocene deposits on the N.W. coast of the Isle of Wight: with an attempt to develop Cuvier's idea of the classification of pachyderms by the number of their toes. Quarterly Journal of the Geological Society of London, 4:103-141. https://doi.org/10.1144/ GSL.JGS.1848.004.01-02.21

Paladilhe, A. 1866. Nouvelles miscellanées malacologiques. Revue et Magasin de Zoologie Pure et Appliquée, Ser.2, 18:168-174.

Pallas, P.S. 1769. Spicilegia Zoologica, Quibus Novae Imprimus et Obscurae Animalium Species Iconibus, Descriptionibus atque Commentariis Illustrantur cura P.S. Pallas. Fasc. 7. G.A. Lange, Berlin.

Pohlig, H. 1885. Über eine Hipparionen-Fauna von Maragha in Nord-Persien, über fossile Elephantenreste Kaukasiens und Persiens. und über die Resultate einer Monographie der fossilen Elephanten Deutschlands und Italien. Zeitschrift der deutschen geologischen Gesellschaft, Berlin, 37(4):1022-1027.

Pomel A. 1892. Sur le Bramus, nuveau type de rongeurs fossile des phosphorites quaternaires de la Berbérie. Comptes Rendus de l'Academie des Sciences, 114:1159-1169.

Popov, V. 2017. Early Pleistocene Small Mammals (Eulipothyphla, Chiroptera, Lagomorpha and Rodentia) from Futjova Cave, North Bulgaria. Acta Zoologica Bulgarica, 69(2):263-282.

Presnyakov, S.L., Belyaeva, E.V., Lyubin, V.P., Radionov, N.V., Antonov, A.V., Saltykova, A.K., Berezhnaya, N.G., and Sergeev, S.A. 2012. Age of the earliest Paleolithic sites in the northern part of the Armenian Highland by SHRIMP-II U-Pb geochronology of zircons from volcanic ashes. Gondwana Research, 21:929-938. https://doi.org/10.1016/j.gr.2011.11.009

Preston, H.B. 1909. Report on a small collection of freshwater Mollusca (Limnaea and Pisidium) from Tibet. Records of Indian Museum, Calcutta, 3, 11(3):115-116.

Rabeder, G. 1981. Die Arvicoliden (Rodentia, Mammalia) aus dem Pliozän und dem älterem Pleistozän von Niederösterreich. Beiträge zur Paläontologie Österreich, 8:1-343.

Radoman, P. 1973. On the relations of some freshwater Mollusca of the Balkan Peninsula and Asia Minor. Basteria, 37:77-84.

Rafinesque, C.S. 1814. Fine del prodromo d'erpetologia siciliana. Specchiodelle Scienze o Giornale Enciclopedico di Sicilia, 2:102-104.

Rafinesque, C.S. 1815. Analyse de Nature, ou Tableau de l'Universe et des Corps Organisés. Jean Barravecchia, Palermo. 
Rafinesque, C.S. 1820. Annals of Nature or Annual Synopsis of New Genera and Species of Animals, Plants, and Discoveries in North America. First Annual Number, for 1820:1-16, T. Smith, Lexington.

Ratnikov, V.Yu. 2001. Osteology of Russian toads and frogs for paleontological researches. Acta Zoologica Cracoviensia, 44:1-23.

Rekovets, L.I. and Nadachowski, A. 1995. Pleistocene voles (Arvicolidae) of the Ukraine. Paleontologia i Evolucio, 28-29:145-245.

Risso, A. 1826. Histoire naturelle des principales productions de l'Europe méridionale, et particulierement de celles des environs de Nice et des Alpes maritimes. Histoire Naturelle Europe Méridionale, 3, F. G. Levrault, Paris \& Strasbourg.

Ritz, J.-F., Avagyan, A., Mkrtchyan, M., Nazari, H., Blard, P.-H., Karakhanian, A., Philip, H., Balescu, S., Mahan, S., Huot, S., Münch, P., Lamothe M., 2016. Active tectonics within the NW and SE extensions of the Pambak-Sevan-Syunik fault: Implications for the present geodynamics of Armenia. Quaternary International, 395:61-78. https://doi.org/10.1016/ j.quaint.2015.05.021

Rutte, E. 1962. Schlundzähne von Süßwasserfische. Palaeontographica A, 120:165-212.

Rzebik-Kowalska, B. 1991. Pliocene and Pleistocene Insectivora (Mammalia) of Poland. VIII. Soricidae: Sorex Linnaeus, 1758, Neomys Kaup, 1829, Macroneomys Fejfar, 1966, Paenelimnoecus Baudelot, 1972 and Soricidae indeterminata. Acta Zoologica Cracoviensia, 34(2):323-424.

Sayadyan, Yu.V. 1970. Stratigraphic position and paleogeographic significance of mammalian fauna of the Leninakan faunal assemblage. Bulletin of Commission for Study of Quaternary, 39:63-67. (In Russian)

Sayadyan, Yu.V. 1972. Significance of Shirak key section for stratigraphy and paleogeography of Pleistocene of Transcaucasia. Bulletin of Commission for Study of Quaternary, 39:58-66. (In Russian)

Sayadyan, Yu.V. 2009. The Newest Geological History of Armenia. Ghitutyun, Yerevan. (In Russian)

Scharrer, S. 2013. Frühpleistozäne Vegetationsentwicklung im Südlichen Kaukasus: Pollenanalytische Untersuchungen an Seesedimenten im Vorotan-Becken (Armenien). Wolfgang Goethe-Universität, Frankfurt am Main. 254 p.

Schütt, H. 1991. Fossile Mollusken dreier anatolischer Ovas. Archiv für Molluskenkunde, 120 (4/ 6):131-147.

Schütt, H. 1997. Altpleistozäne Mollusken im Becken von Pasinler bei Erzurum, Türkei. Geologica et Palaeontologica, 31:275-284.

Schütt, H. and Mansoorian, T. 1999. A new freshwater hydrobiid snail from İran. Club Conchylia Informationen, 31(3/4):10-14.

Schütt, H. and Yildirim, Z.A. 1999. A new freshwater snail from the Beyşehir Lake in South-west Anatolia (Gastropoda: Prosobranchia: Hydrobioidea). Malakologische Abhandlungen, 19(22): 243-246.

Sélys-Longchamps, E. 1845. Elenco de'topi compagnoli (Arvicoli) d'Europa, p. 319-322. In Atti Della Sesta Riunione Degli Scienziati Italiani Tenuta in Milano nel Settembre del 1844. Luigi di Giacomo Pirola, Milano.

Shalaeva, E.A., Trifonov, V.G., Lebedev, V.A., Simakova, A.N., Avagyan, A.V., Sahakyan, L.H., Arakelyan, D.A., Sokolov, S.A., Bachmanov, D.M., Kolesnichenko, A.A., Latyshev, A.V., Belyaeva, E.V., Lyubin, V.P., Frolov, P.D., Tesakov, A.S., Sychevskaya, E.K., Kovalyova, G.V., Martirosyan, M., and Khisamutdinova, A.I. 2019. Quaternary geology and origin of the Shirak Basin, NW Armenia. Quaternary International, 509:41-61. https://doi.org/10.1016/ j.quaint.2018.09.017.

Shatilova, I., Mchedlishvili, N., Rukhadze, L., and Kvavadze, E. 2011. The History of the Flora and Vegetation of Georgia (South Caucasus). Georgian National Museum, Institute of Paleobiology, Tbilisi.

Shatilova, N.I. 1974. Palynological Evidence of Upper Pliocene and Pleistocene Geochronology in Western Georgia. Metsniereba, Tbilisi. (In Russian)

Sheppard, R. 1823. Description of seven new British land and fresh-water shells, with observations upon many other species, including a list of such as have been found in the country of Suffolk. Transactions of the Linnean Society of London, 14(1):148-170.

Sher, A.V. 1971. Mammals and Pleistocene Stratigraphy of the Extreme North-east of the USSR and North America. Nauka, Moscow. (In Russian) 
Stelfox, A.W. 1918. The Pisidium fauna of the Great Junction Canal in Herts. and Bucks. Journal of Conchology, 15(10):289-304.

Stöck, M., Moritz, C., Hickerson, M., Frynta, D., Dujsebayeva, T., Eremchenko, V., Macey, J.R., Papenfuss, T.J., and Wake, D.B. 2006. Evolution of mitochondrial relationships and biogeography of Palearctic green toads (Bufo viridis subgroup) with insights in their genomic plasticity. Molecular Phylogenetics and Evolulion, 41:663-689. https://doi.org/10.1016/ j.ympev.2006.05.026

Stöck, M., Sicilia, A., Belfiore, N., Buckley, D., Lo Brutto, S., Lo Valvo, M., and Arculeo, M. 2008. Post-Messinian evolutionary relationships across the Sicilian channel: mitochondrial and nuclear markers link a new green toad from Sicily to African relatives. BMC Evolutionary Biology, 8:56-74. https://doi.org/10.1186/1471-2148-8-56

Studer, S. 1820. Kurzes Veszeichniss der bis jetzt in unzern Vaterlande entdecken Conchylien. Naturvissenschaften Anziger Schweizarischen Gezellschaft, 3:83-94.

Sytchevskaya, E. 1986. Paleogene freshwater fish fauna of the USSR and Mongolia. Transactions of the Joint Soviet-Mongolian Paleontological Expedition, 29:1-158. (In Russian)

Sytchevskaya, E. 1989. Neogene freshwater fish fauna of Mongolia. Transactions of the Joint Soviet-Mongolian Paleontological Expedition, 39:1-144. (In Russian)

Tadevosyan, T.L. 2004-2009. Tadevosyan's Herpetological Resources. http://www.herpam.narod.ru/. Accessed May 2017.

Tagieva, E.N. 2011. Evolution of Vegetation and Climate of Azerbaijan in Cenozoic. Abridged thesis of Doctor of Geographic Sciences. Institute of Geography. National Academy of Sciences of Azerbaijan, Baku. (In Russian)

Terzea, E. 1970. Sur l'apparition et l'evolution de quelqes genres d'Arvicolides pendat le Pleistocene, p. 499-511. In Orghidan, T. (ed.), Livre du Centenaire Emile G. Racovitza 18681968. Académie de la République socialiste de Roumanie, Bucuresti.

Terzea, E. 1989. Les Arvicolides (Rodentia, Mammalia) du Pleistocene moyen de Chiscau-1 (depart. de Bihor, Roumanie). Travaux de I'Institut Spéologie "Emile Racovitza", 28:57-72.

Tesakov, A.S. 2016. Early Middle Pleistocene Ellobius (Rodentia, Cricetidae, Arviclinae) from Armenia. Russian Journal of Theriology, 15(2):151-158. https://doi.org/10.15298/ rusjtheriol.15.2.07

Tesakov, A.S., Dodonov, A.E., Titov, V.V., and Trubikhin, V.M. 2007. Plio-Pleistocene geological record and small mammal faunas, eastern shore of the Azov Sea, Southern European Russia. Quaternary International, 160(1):57-69. https://doi.org/10.1016/j.quaint.2006.09.009

Topachevsky, V.A. 1965. Insectivores and Rodents of the Late Pliocene Fauna of Nogaisk. Naukova Dumka, Kiev. (In Russian)

Tougard, C. 2017. Did the Quaternary climatic fluctuations really influence the tempo and mode of diversification in European rodents? Journal of Zoological Systematics and Evolutionary Research, 55:46-56. https://doi.org/10.1111/jzs.12152

Trifonov, V.G., Shalaeva, E.A., Saakyan, L.Kh., Bachmanov, D.M., Lebedev, V.A., Trikhunkov, Ya.I., Simakova, A.N., Avagyan, A.V., Tesakov, A.S., Frolov, P.D., Lyubin, V.P., Belyaeva, E.V., Latyshev, A.V., Ozherelyev, D.V., and Kolesnichenko, A.A. 2017. Quaternary tectonics of recent basins in northwestern Armenia. Geotectonics, 51(5):499-519. https://doi.org/ 10.1134/S0016852117030116

Trifonov, V.G., Lyubin, V.P., Belyaeva, E.V., Lebedev, V.A., Trikhunkov, Ya. I., Tesakov, A.S., Simakova, A.N., Veselovsky, R.V., Latyshev, A.V., Presnyakov, S.L., Ivanova, T.P., Ozhereliev, D.V., Bachmanov, D.M., and Lyapunov, S.M. 2016. Stratigraphic and tectonic settings of Early Paleolithic of North-West Armenia. Quaternary International, 420:178-198. https://doi.org/10.1016/j.quaint.2015.08.019

Ünay, E. 1998. Allophaiomys from Turkey. Paludicola, 2:106-109.

van den Hoek Ostende, L.W., Gardner, J. D., van Bennekom, L., Alçiçek, M.C., Murray, A., Wesselingh, F.P., Alçiçek, H., and Tesakov, A. 2015. Ericek, a new Pliocene vertebrate locality in the Çameli Basin (southwestern Anatolia, Turkey). Palaeobiodiversity and Palaeoenvironvents, 95(3):305-320. https://doi.org/10.1007/s12549-015-0202-3

van der Meulen, A. 1973. Middle Pleistocene smaller mammals from the Monte Peglia (Orivieto, Italy) with special reference to the phylogeny of Microtus (Arvicolidae, Rodentia).

Quaternaria, 17:1-144. 
Vasilyan, D. 2008a. New fossil species of dace Leuciscus (Telestes) cf. souffia Risso,1826 from Pleistocene deposits of Ararat valley of Armenia. Biological Journal of Armenia, 60(1-2):113117. (In Russian)

Vasilyan, D. 2008b. Ichthyofauna of the Pliocene-Pleistocene of Armenia and its significance for paleoclimatological studies. Vestnik MANEB (Saint-Petersburg), 13(4-2):60-65. (In Russian)

Vasilyan, D. 2009. Lower Vertebrates of the Late Paleogene and Neogene of Armenia. Abridged Ph.D. Thesis, Scientific Center of Zoology and Hydroecology, National Academy of Sciences of Republic of Armenia, Yerevan.

Vasilyan, D. and Carnevale, G. 2013. The Afro-Asian labeonine genus Garra Hamilton, 1822

(Teleostei, Cyprinidae) in the Pliocene of Central Armenia: Palaeoecological and palaeobiogeographical implications. Journal of Asian Earth Sciences, 62:788-796. https:// doi.org/10.1016/j.jseaes.2012.11.033

Vasilyan, D., Schneider, S., Bayraktutan, M.S., and Şen, Ş. 2014. Early Pleistocene freshwater communities and rodents from the Pasinler Basin (Erzurum Province, north-eastern Turkey). Turkish Journal of Earth Sciences, 23:293-307. https://doi.org/10.3906/yer-1307-16

Vekua, A.K. 1962. The Lower Pleistocene Mammalian Fauna of Akhalkalaki. Akademy of Sciences of Georgian SSR, Tbilisi. (In Georgian with Russian abstract)

Vekua, A.K. 1986. The Lower Pleistocene mammalian fauna of Akhalkalaki (southern Georgia, USSR). Palaeontographia Italica,74:63-96.

von Koenigswald, W. and van Kolfschoten, T. 1996. The Mimomys-Arvicola boundary and the enamel thickness quotient (SDQ) of Arvicola as stratigraphic markers in the Middle Pleistocene, p. 211-226. In Turner, Ch. (ed.), The Early Middle Pleistocene in Europe. Balkema, Rotterdam.

Waddell, P.J., Okada, N., and Hasegawa, M. 1999. Towards resolving the interordinal relationships of placental mammals. Systematic Biology, 48(1):1-5.

Weber, A. 1927. Eine neue Pyrgula. Pyrgula pfeiferi m. Zoologischer Anzeiger, 70:313-314.

Wilke, T., Albrecht, C., Anistratenko, V.V., Sahin, S.K., and Yildirim, M.Z. 2007. Testing biogeographical hypotheses in space and time: faunal relationships of the putative ancient Lake Eğirdir in Asia Minor. Journal of Biogeography, 34(10):1807-1821. https://doi.org/ 10.1111/j.1365-2699.2007.01727.x

Yildirim, M. Z. 1999. The Prosobranchia (Gastropoda: Mollusca) species of Turkey and their zoogeographic distribution. 1. Fresh and brackish water. Turkish Journal of Zoology, 23:877900. (In Turkish)

Zaikina, N.G., Sayadyan, Yu.V., and Sokolova, N.S. 1969b. Data of spore and pollen, and diatom analyses of the paleo-lacustrine deposits of the Leninakan Lake, p. 105-113. In Markov, K.K. (ed.), Neotectonics, Recent Deposits and Humans, Vol. 1. Moscow State University Press, Moscow. (In Russian)

Zaikina, N.G., Sayadyan, Yu.V., and Sokolova, N.S. 1969a. On history of vegetation in the Shirak plain. Biological Journal of the Academy of Sciences of the Armenian SSR, 22(4):67-74. (In Russian)

Zaitsev, M.V. and Baryshnikov, G.F. 2002. Pleistocene Soricidae (Lipotyphla, Insectivora, Mammalia) from Treugolnaya Cave, Northern Caucasus, Russia. Acta Zoologica Cracoviensia, 45(2):283-305.

Zazhigin, V.S. 1970. Significance of Lagurins (Rodentia, Microtinae, Lagurini) for stratigraphy and correlation of Eopleistocene deposits of Eastern Europe and Western Siberia. Palaeogeography, Palaeoclimatology, Palaeoecology, 8(2/3):237-249. https://doi.org/ 10.1016/0031-0182(70)90016-7

Zhadin, V.I. 1952. Mollusca of Fresh and Brackish Waters of the USSR. Identification reference books on the fauna of the USSR published by the Zoological Institute of the Academy of Sciences of the USSR, 46. USSR Academy of Sciences, Moscow-Leningrad. (In Russian)

Zhegallo, V.I. 1988. Family Equidae. In Nikiforova, K.V. and Vangengeim, E.A. (eds.), Biostratigraphy of Late Pliocene-Early Pleistocene of Tajikistan (on the basis of mammal fauna). Nauka, Moscow. (In Russian) 